\title{
Clinical Role of Extraoral Bitter Taste Receptors
}

\author{
Joanna Jeruzal-Świątecka ${ }^{1, * \mathbb{C}}$, Wojciech Fendler ${ }^{2,3}$ and Wioletta Pietruszewska ${ }^{1}$ \\ 1 Department of Otolaryngology, Head and Neck Oncology, Medical University of Lodz, 90-419 Lodz, Poland; \\ wioletta.pietruszewska@umed.lodz.pl \\ 2 Department of Biostatistics and Translational Medicine, Medical University of Lodz, 90-419 Lodz, Poland; \\ wojciech.fendler@umed.lodz.pl \\ 3 Department of Radiation Oncology, Dana-Farber Cancer Institute, Boston, MA 02115, USA \\ * Correspondence: joanna.jeruzal@gmail.com; Tel.: +48-501-785-470
}

Received: 26 June 2020; Accepted: 16 July 2020; Published: 21 July 2020

check for updates

\begin{abstract}
Humans can recognise five basic tastes: sweet, sour, salty, bitter and umami. Sour and salty substances are linked to ion channels, while sweet, bitter and umami flavours are transmitted through receptors linked to the $G$ protein ( $G$ protein-coupled receptors; GPCRs). There are two main types of GPCRs that transmit information about sweet, umami and bitter tastes-the Tas1r and TAS2R families. There are about 25 functional TAS2R genes coding bitter taste receptor proteins. They are found not only in the mouth and throat, but also in the intestines, brain, bladder and lower and upper respiratory tract. The determination of their purpose in these locations has become an inspiration for much research. Their presence has also been confirmed in breast cancer cells, ovarian cancer cells and neuroblastoma, revealing a promising new oncological marker. Polymorphisms of TAS2R38 have been proven to have an influence on the course of chronic rhinosinusitis and upper airway defensive mechanisms. TAS2R receptors mediate the bronchodilatory effect in human airway smooth muscle, which may lead to the creation of another medicine group used in asthma or chronic obstructive pulmonary disease. The discovery that functionally compromised TAS2R receptors negatively impact glucose homeostasis has produced a new area of diabetes research. In this article, we would like to focus on what facts have been already established in the matter of extraoral TAS2R receptors in humans.
\end{abstract}

Keywords: bitter taste receptors; TAS2R; biomarker; human tissue; taste; genetic background; receptor signalling; chronic rhinosinusitis; asthma; obesity; diabetes; cancer

\section{Introduction}

Humans can recognise five basic tastes: sweet, sour, salty, bitter and umami, which is the taste of glutamate acid, described as the taste of "broth" or "meat". Taste is one of the basic senses available to organisms and is used mainly for the chemical analysis of food composition. Taste recognition begins at the taste receptors, which are found in the taste buds on the mucous of the tongue, palate and throat. These taste buds contain elongated receptor cells, which contact the microvilli with substances dissolved in oral cavity fluids. Each specific receptor cell detects a certain type of taste and triggers the potential for transmitting taste information in various mechanisms. Sour and salty substances are linked to ion channels, while sweet, bitter and umami flavours are transmitted through receptors linked to the $G$ protein [1-6]. The molecular sensors for all five taste groups act through second messenger systems to initiate neural signalling. These second messenger systems include phospholipase C-, cyclic $\mathrm{AMP}$ - and $\mathrm{IP}_{3}$-responsive mechanisms. In many cases, the second messenger systems cause the release of calcium from intracellular stores, leading to the initiation of cell depolarisation and the transmission of neural impulses to the brain via the chorda tympani and glossopharyngeal nerves [7]. 
However, each person experiences flavours a little differently and reacts differently to certain substances. An example of such a reaction may be the recognition of the taste of phenylthiocarbamide (PTC). A chance discovery made by Fox in 1931 revealed that although many individuals perceive PTC as intensely bitter, this substance is relatively tasteless to a large fraction of the population [8]. This discovery led to further research into the genetic determinants of taste sensation. Among other things, it was found that there are two main types of receptors linked with the $G$ protein ( $G$ protein-coupled receptors; $\mathrm{GPCR}_{\mathrm{S}}$ ) that transmit information about sweet, umami and bitter tastes. They were named the Tas1r family and TAS2R family of receptors and the DNA coding regions were designated as the TAS1R and TAS2R genes. TAS2R receptors detect ingested bitter compounds such as toxic plant alkaloids, while TAS1R detects sugars such as glucose and sucrose. There are about 25 functional $T A S 2 R$ genes that code bitter taste receptor proteins, while there are only three TAS1R genes that code sweet and umami taste receptors [2,9] (Figure 1). It has been proven that these taste receptors are found not only in the mouth and throat, but also in the intestines, brain, bladder, lower and upper respiratory tract and pancreas [10] (Table 1). Research has therefore been undertaken to determine the purpose of their presence in these locations, and the suspicion has been raised that they must be involved in initiating the body's immune system reactions as an additional defence mechanism. Much research has been already undertaken in mouse and rat models, and this work has been reviewed in other articles [11,12]. In this article, we would like to focus on what facts have been already established in the matter of extraoral TAS2R receptors in humans.

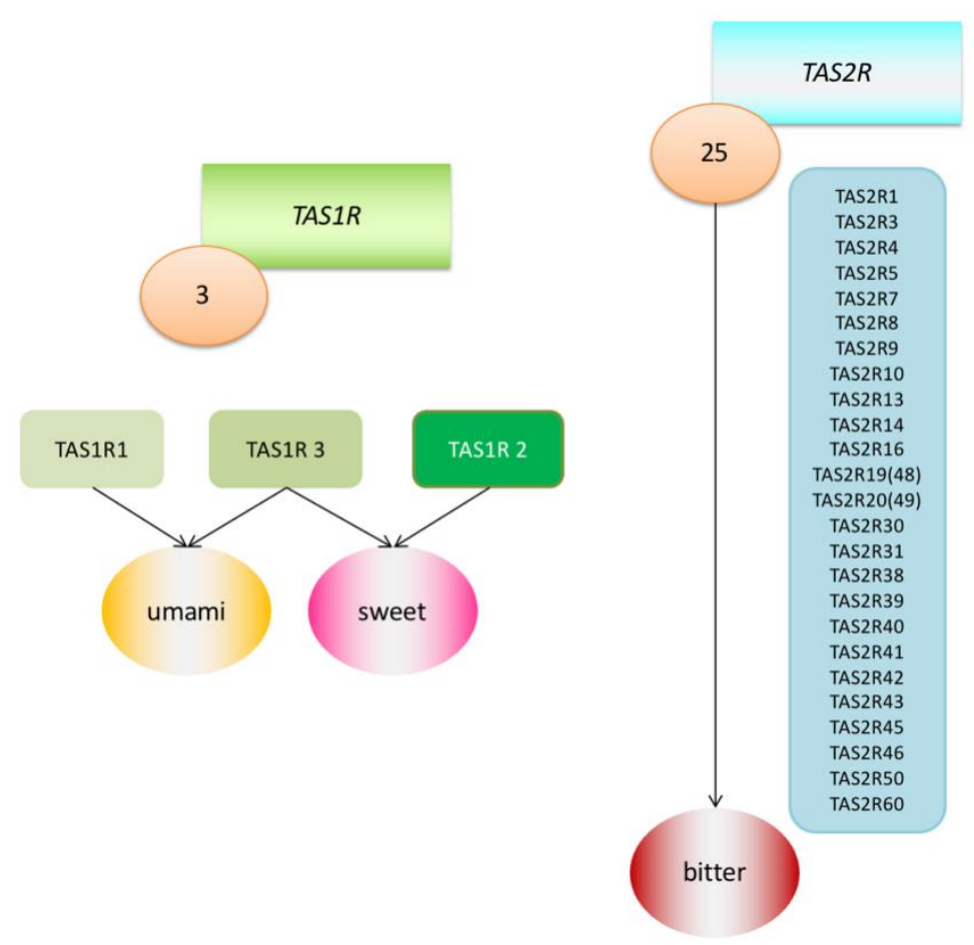

Figure 1. Graphic model of Tas1r (TAS1R1, TAS1R2, TAS1R3) and TAS2R (25 TAS2Rs) receptor families. 
Table 1. Selected studies on TAS2R receptors in different human tissue lines.

\begin{tabular}{|c|c|c|c|c|}
\hline Author & Tissue & TAS2R & Method & Main Outcome \\
\hline $\begin{array}{l}\text { Mennella } \\
2005[13]\end{array}$ & buccal mucosa cells & TAS2R38 & qRT-PCR & $\begin{array}{l}\text { Genotypes at the TAS2R38 locus were } \\
\text { significantly related to preferences for } \\
\text { sucrose and sweet-tasting beverages } \\
\text { and foods, such as cereals, in children } \\
\text { but not in adults. }\end{array}$ \\
\hline $\begin{array}{l}\text { Rozengurt } \\
2006[14]\end{array}$ & $\begin{array}{l}\text { cultured intestinal } \\
\text { HuTu-80 and } \\
\text { NCI-H716 cell lines }\end{array}$ & $\begin{array}{c}\text { TAS2R3/4/5 } \\
\text { TAS2R10/13/14 } \\
\text { TAS2R38/39 } \\
\text { TAS2R39 } \\
\text { TAS2R40/42/43/44/45/46/47 } \\
\text { TAS2R50 } \\
\text { TAS2R60 }\end{array}$ & qRT-PCR & $\begin{array}{l}\text { NCI-H716 and HuTu-80 express } \\
\text { transcripts that encode the GI } \\
\text { peptides PYY and GIP and the } \\
\text { precursor for glucagon/GLP-1, and its } \\
\text { secretion may be via TAS2R receptors. }\end{array}$ \\
\hline $\begin{array}{l}\text { Shah } 2009 \\
{[15]}\end{array}$ & airway epithelium & $\begin{array}{c}\text { TAS2R4 } \\
\text { TAS2R38 } \\
\text { TAS2R } 43 / 46\end{array}$ & qRT-PCR & $\begin{array}{l}\text { TAS2Rs are localised in cilia, and their } \\
\text { signalling pathway is functional. }\end{array}$ \\
\hline $\begin{array}{l}\text { Deshpande } \\
2010[16]\end{array}$ & $\begin{array}{l}\text { cultured airway } \\
\text { smooth muscle } \\
\text { (ASM) }\end{array}$ & $\begin{array}{l}\text { TAS2R10/14 } \\
\text { TAS2R31 }\end{array}$ & qRT-PCR & $\begin{array}{l}\text { Bitter tastant induces bronchodilatory } \\
\text { effect mediated by TAS2Rs. }\end{array}$ \\
\hline $\begin{array}{c}\text { Le Neve } 2010 \\
{[17]}\end{array}$ & $\begin{array}{l}\text { duodenal cell line } \\
\text { HuTu-80 }\end{array}$ & $\begin{array}{l}\text { TAS2R7 } \\
\text { TAS2R14 }\end{array}$ & qRT-PCR & $\begin{array}{l}\text { H.g.-12, a steroid glycoside purified } \\
\text { from } H \text {. gordonii extract, activates } \\
\text { human bitter receptors TAS2R7 and } \\
\text { TAS2R14. }\end{array}$ \\
\hline $\begin{array}{c}\text { Jeon } 2011 \\
{[18]}\end{array}$ & $\begin{array}{l}\text { epithelial colorectal } \\
\text { cell line Caco-2 }\end{array}$ & TAS2R38 & qRT-PCR & $\begin{array}{l}\text { Phenylthiocarbamide was found to } \\
\text { increase ATP-binding cassette B1 } \\
\text { expression and increases its efflux } \\
\text { activity. }\end{array}$ \\
\hline Lee 2012 [19] & $\begin{array}{l}\text { sinonasal epithelial } \\
\text { cells }\end{array}$ & TAS2R38 & qRT-PCR & $\begin{array}{l}\text { The TAS2R38 genotype represents a } \\
\text { defining characteristic in respiratory } \\
\text { innate defence that contributes to the } \\
\text { complex genetic and environmental } \\
\text { interactions predisposing humans to } \\
\text { upper respiratory infections. }\end{array}$ \\
\hline $\begin{array}{l}\text { Grassin-Delyle } \\
\quad 2013[20]\end{array}$ & lung tissue & $\begin{array}{c}\text { TAS2R5/7 } \\
\text { TAS2R10/14 } \\
\text { TAS2R38/39 } \\
\text { TAS2R43 }\end{array}$ & qRT-PCR & $\begin{array}{l}\text { TAS2R } 5,10 \text { and } 14 \text { are involved in the } \\
\text { relaxation of human bronchi. }\end{array}$ \\
\hline $\begin{array}{l}\text { Orsmark-Pietras } \\
\quad 2013[21]\end{array}$ & $\begin{array}{l}\text { WBC from children } \\
\text { with severe asthma } \\
\text { and } \\
\text { WBC from healthy } \\
\text { children }\end{array}$ & $\begin{array}{c}\text { TAS2R } 4 / 5 \\
\text { TAS2R } 10 / 13 / 14 / 19 \\
\text { TAS2R20 } \\
\text { TAS2R31 } \\
\text { TAS } 2 R 45 / 46 \\
\text { TAS2R50 }\end{array}$ & qRT-PCR & $\begin{array}{l}\text { The expression of most bitter taste } \\
\text { receptors was higher in children with } \\
\text { severe asthma compared to the } \\
\text { healthy controls, and these differences } \\
\text { reached statistical significance for } \\
\text { TAS2R13, TAS2R14 and TAS2R19. The } \\
\text { expression of all bitter taste receptors } \\
\text { was significantly greatest in the } \\
\text { lymphocyte population compared to } \\
\text { monocytes. }\end{array}$ \\
\hline $\begin{array}{c}\text { Foster } 2013 \\
\quad[22]\end{array}$ & heart tissue & $\begin{array}{c}\text { TAS2R3/4/5 } \\
\text { TAS2R13/14/19(48) } \\
\text { TAS2R20(49) } \\
\text { TAS2R30/31 } \\
\text { TAS2R } 43 / 45 / 46 \\
\text { TAS2R50 }\end{array}$ & qRT-PCR & $\begin{array}{l}\text { TAS2R14 was the most expressed } \\
\text { TAS2R in human heart tissue. }\end{array}$ \\
\hline $\begin{array}{c}\text { Lund } 2013 \\
\quad[23]\end{array}$ & $\begin{array}{c}\text { mesenchymal } \\
\text { stromal cells (MSC) }\end{array}$ & TAS2R46 & qRT-PCR & $\begin{array}{l}\text { Human bone marrow expresses the } \\
\text { TAS2R46 receptor, and it is functional. }\end{array}$ \\
\hline $\begin{array}{l}\text { Singh } 2014 \\
{[24]}\end{array}$ & $\begin{array}{l}\text { mammary } \\
\text { epithelial cell lines } \\
\text { MCF-10A, MCF-7 } \\
\text { and MDA-MB-231 }\end{array}$ & $\begin{array}{l}\text { TAS2R1/4 } \\
\text { TAS2R10 } \\
\text { TAS2R20(49) } \\
\text { TAS2R38 }\end{array}$ & qRT-PCR & $\begin{array}{l}\text { TAS2R } 4 \text { was the highest expressed } \\
\text { TAS2R in normal mammary epithelial } \\
\text { cells compared to breast cancer cells. }\end{array}$ \\
\hline
\end{tabular}


Table 1. Cont.

\begin{tabular}{|c|c|c|c|c|}
\hline Author & Tissue & TAS2R & Method & Main Outcome \\
\hline $\begin{array}{l}\text { Ekoff } 2014 \\
\quad[25]\end{array}$ & $\begin{array}{l}\text { cord blood-derived } \\
\text { mast cells (CBMCs) } \\
\text { and the mast cell } \\
\text { line HMC1.2 }\end{array}$ & $\begin{array}{c}\text { TAS2R3/4/5 } \\
\text { TAS2R10/14/19 } \\
\text { TAS2R20(49) } \\
\text { TAS2R46 }\end{array}$ & qRT-PCR & $\begin{array}{l}\text { TAS2Rs mediated significant } \\
\text { inhibition of the release of histamine } \\
\text { and PGD2 from } \\
\text { IgE-receptor-activated primary } \\
\text { human mast cells. The TAS2Rs may } \\
\text { mediate anti-inflammatory responses. }\end{array}$ \\
\hline $\begin{array}{c}\text { Clark 2015 } \\
{[26]}\end{array}$ & $\begin{array}{l}\text { thyroid cells, } \\
\text { thyrocyte line Nthy } \\
\text { Ori 3-1 }\end{array}$ & $\begin{array}{c}\text { TAS2R4 } \\
\text { TAS2R10 } \\
\text { TAS2R38 } \\
\text { TAS2R42/43 }\end{array}$ & qRT-PCR & $\begin{array}{l}\text { TAS2R } 42 \text { is associated with } \\
\text { differences in the circulating levels of } \\
\text { thyroid hormones. }\end{array}$ \\
\hline Yu 2015 [27] & $\begin{array}{l}\text { enteroendocrine } \\
\text { NCI-H716 cells }\end{array}$ & TAS2R38 & qRT-PCR & $\begin{array}{l}\text { GLP-1 secretion was significantly } \\
\text { increased by berberine incubation, } \\
\text { which was concentration-dependently } \\
\text { inhibited by the TAS2R38 antibody. }\end{array}$ \\
\hline $\begin{array}{l}\text { Wölfle } 2015 \\
\text { [28] }\end{array}$ & $\begin{array}{l}\text { primary } \\
\text { keratinocytes } \\
\text { (HPKs), } \\
\text { keratinocyte cell } \\
\text { line HaCaT } \\
\end{array}$ & $\begin{array}{c}\text { TAS2R1 } \\
\text { TAS2R38 }\end{array}$ & qRT-PCR & $\begin{array}{l}\text { TAS2R expression was shown } \\
\text { throughout the epidermis, but it was } \\
\text { weak in the basal cells. }\end{array}$ \\
\hline $\begin{array}{l}\text { Wölfle } 2016 \\
\text { [29] }\end{array}$ & $\begin{array}{l}\text { placental cell line } \\
\text { JEG-3 }\end{array}$ & TAS2R38 & qRT-PCR & $\begin{array}{l}\text { The expression of fully functional } \\
\text { TAS2R38 receptors was found in } \\
\text { placental tissue. }\end{array}$ \\
\hline \multirow[t]{5}{*}{$\begin{array}{l}\text { Jaggupilli } \\
2017[30]\end{array}$} & $\begin{array}{l}\text { cystic fibrosis } \\
\text { bronchial epithelial } \\
\text { cells (CuFi-1) } \\
\text { normal bronchial } \\
\text { epithelial cells } \\
\text { (NuLi-1) }\end{array}$ & $\begin{array}{c}\text { TAS2R3/4/5 } \\
\text { TAS2R10/13/14/19(48) } \\
\text { TAS2R320(49) }\end{array}$ & \multirow[t]{5}{*}{ qRT-PCR } & \multirow{5}{*}{$\begin{array}{l}\text { The expression of TAS2R } 14 \text { and } \\
\text { TAS2R20 (49) is much higher in breast } \\
\text { cancer cells than in normal mammary } \\
\text { tissue. }\end{array}$} \\
\hline & $\begin{array}{c}\text { airway smooth } \\
\text { muscle cells (ASM) }\end{array}$ & $\begin{array}{c}\text { TAS2R14 } \\
\text { TAS2R20(49) } \\
\text { TAS2R50 }\end{array}$ & & \\
\hline & $\begin{array}{l}\text { pulmonary artery } \\
\text { smooth muscle } \\
\text { (PASM) }\end{array}$ & $\begin{array}{l}\text { TAS2R14 } \\
\text { TAS2R20(49) } \\
\text { TAS2R50 } \\
\end{array}$ & & \\
\hline & $\begin{array}{l}\text { mammary } \\
\text { epithelial cells } \\
\text { MCF-10A }\end{array}$ & $\begin{array}{c}\text { TAS2R14 } \\
\text { TAS2R20(49) }\end{array}$ & & \\
\hline & $\begin{array}{l}\text { breast cancer cells } \\
\text { MDA-MB-231 }\end{array}$ & $\begin{array}{c}\text { TAS2R14 } \\
\text { TAS2R20(49) }\end{array}$ & & \\
\hline $\begin{array}{c}\text { Latorre } 2016 \\
{[31]}\end{array}$ & $\begin{array}{l}\text { colonic mucosal } \\
\text { calls }\end{array}$ & TAS2R38 & qRT-PCR & $\begin{array}{l}\text { TAS2R38 is expressed by the human } \\
\text { colonic mucosa, where it is localised } \\
\text { to distinct types of enteroendocrine } \\
\text { cells (EEC), including cholecystokinin } \\
\text { (CCK), glucagon-like peptide- } 1 \\
\text { (GLP-1) and peptide YY (PYY) cells. }\end{array}$ \\
\hline $\begin{array}{c}\text { Zheng } 2017 \\
{[32]}\end{array}$ & $\begin{array}{l}\text { myometrial cells, } \\
\text { hTERT-HM cells }\end{array}$ & $\begin{array}{c}\text { TAS2R1/3/4/5/7/8/9 } \\
\text { TAS2R10/13/14/16/19 } \\
\text { TAS2R20 } \\
\text { TAS2R30/31/38/39 } \\
\text { TAS2R40 }\end{array}$ & qRT-PCR & $\begin{array}{l}\text { Human myometrial cells express } \\
\text { TAS2Rs and the activation of the } \\
\text { canonical TAS2R signalling system by } \\
\text { bitter tastants in myometrial cells } \\
\text { produces profound relaxation of the } \\
\text { myometrium. }\end{array}$ \\
\hline $\begin{array}{c}\text { Hariri } 2017 \\
{[33]}\end{array}$ & sinonasal tissue & $\begin{array}{l}\text { TAS2R14 } \\
\text { TAS2R38 }\end{array}$ & qRT-PCR & $\begin{array}{l}\text { Flavones activate TAS2R14 expression } \\
\text { in sinonasal epithelial cell cilia. }\end{array}$ \\
\hline $\begin{array}{l}\text { Freud } 2018 \\
{[34]}\end{array}$ & sinonasal tissue & $\begin{array}{l}\text { TAS2R4 } \\
\text { TAS2R14/16 } \\
\text { TAS2R38 }\end{array}$ & qRT-PCR & $\begin{array}{c}\text { All examined TAS2Rs are activated by } \\
\text { bacterial ligands. }\end{array}$ \\
\hline
\end{tabular}


Table 1. Cont.

\begin{tabular}{|c|c|c|c|c|}
\hline Author & Tissue & $T A S 2 R$ & Method & Main Outcome \\
\hline $\begin{array}{c}\text { Shaw } 2018 \\
{[35]}\end{array}$ & skin cells & $\begin{array}{c}\text { TAS2R3/4/5/9 } \\
\text { TAS2R } 13 / 14 / 16 / 19 \\
\text { TAS2R20 } \\
\text { TAS2R30/31/38/39 } \\
\text { TAS2R } 40 / 41 / 42 / 43 / 45 / 46 \\
\text { TAS2R } 50 \\
\text { TAS2R } 60\end{array}$ & qRT-PCR & $\begin{array}{c}\text { There are differences in TAS2R } \\
\text { expression in the skin concerning sun } \\
\text { exposure, sex and age. }\end{array}$ \\
\hline $\begin{array}{l}\text { Grassin-Delyle } \\
2019 \text { [36] }\end{array}$ & $\begin{array}{l}\text { lung macrophages } \\
\text { (LM) }\end{array}$ & $\begin{array}{l}\text { TAS2R3/4/5/7/8/9 } \\
\text { TAS2R } 10 / 14 / 19 \\
\text { TAS2R20 } \\
\text { TAS2R31/38/39 } \\
\text { TAS2R } 43 / 45 / 46\end{array}$ & qRT-PCR & $\begin{array}{l}\text { TAS2Rs are expressed in human LMs, } \\
\text { and TAS2R agonists inhibit } \\
\text { LPS-induced cytokine release by } \\
\text { LMs-a process that is not mediated } \\
\text { by the release of IL-10. }\end{array}$ \\
\hline $\begin{array}{c}\text { Cont } 2019 \\
{[37]}\end{array}$ & buccal mucosa & TAS2R38 & qRT-PCR & $\begin{array}{l}\text { Infants insensitive to bitter taste } \\
\text { (AVI/AVI) were more likely to } \\
\text { consume the whole first } \\
\text { complementary food meal at the first } \\
\text { attempt, compared to sensitive ones } \\
\text { (AVI/PAV or PAV/PAV). }\end{array}$ \\
\hline $\begin{array}{l}\text { Governini } \\
2020[38]\end{array}$ & $\begin{array}{l}\text { semen cells, } \\
\text { testicular tissue }\end{array}$ & $\begin{array}{c}\text { TAS2R3/4 } \\
\text { TAS2R } 14 / 19 \\
\text { TAS2R } 43\end{array}$ & ddPCR & $\begin{array}{c}\text { TAS2R14 is the most expressed bitter } \\
\text { receptor subtype in both testis tissue } \\
\text { and sperm cells. In vitro capacitation } \\
\text { significantly affects the expression } \\
\text { and the subcellular localisation of } \\
\text { TAS2R receptors in isolated } \\
\text { spermatozoa. }\end{array}$ \\
\hline
\end{tabular}

GI = gastrointestinal, PYY = peptide YY, GIP = gastric inhibitory peptide, GLP-1 = glucagon-like peptide-1, PGD2 = prostaglandin D2, EEC = enteroendocrine cells, CCK = cholecystokinin, ASM = airway smooth muscle, PASM $=$ pulmonary artery smooth muscle, $\mathrm{LM}=$ lung macrophages, $\mathrm{CBMCs}=$ cord blood-derived mast cells, $\mathrm{MSC}=$ mesenchymal stromal cells, WBC = white blood cells, HPKs = human primary keratinocytes.

\section{TAS2R Bitter Taste Receptor Activation and Intracellular Signalling Cascades}

TAS2Rs are, as mentioned before, G protein-like receptors. GPCRs specifically connected to sweet and bitter taste receptors couple to specific intracellular $G$ proteins. $G \alpha$-gustducin is involved in sweet and bitter taste transduction, and $\mathrm{G} \gamma 13$ is exclusively for bitter taste perception [39-41]. When TAS2R receptors are stimulated with known agonists such as denatonium, 6-n-propyl-2-thiouracil (PROP) or phenylthiocarbamide (PTC), the reaction goes in two ways. Activated $\alpha$-gustducin stimulates a taste phosphodiesterase (PDE) to hydrolyse cAMP. These decreased levels of cAMP may disinhibit cyclic nucleotide-inhibited channels (cNMP) and in consequence, elevate intracellular $\mathrm{Ca}^{2+}$, promoting neurotransmitter release [42]. The subsequent steps in the $\alpha$-gustducin-PDE-cNMP pathway are still uncertain. The second pathway leads through the $\beta$ and $\gamma$ subunits of gustducin (identified as G $\beta 3$ and $G \gamma 13$ ) which activate phospholipase $C$ isoform $\beta 2$ (PLC $\beta 2)$ to generate inositol trisphosphate $\left(\mathrm{IP}_{3}\right)$. The released $\mathrm{IP}_{3}$ binds to IP3 receptor type III (IP3RIII). This mechanism leads to the release of $\mathrm{Ca}^{2+}$ from internal stores [43]. Elevated levels of $\mathrm{Ca}^{2+}$ activate transient receptor potential proteins (TRP) within the taste receptor, especially TRPM5, which is known to be abundantly expressed in taste receptor cells that are involved in sweet, amino acid and bitter perception [44-46]. TRPM5 is a necessary component of sweet, amino acid and bitter taste reception, although it is still not certain what the true role of $\mathrm{Ca}^{2+}$ is in its response [47].

A fascinating discovery is also that the number of compounds perceived by humans as bitter is much larger than the number of human TAS2R genes [48]. This implies that each TAS2R receptor responds to more than one bitter ligand [49]. Several TAS2Rs, such as TAS2R7, TAS2R14 and TAS2R46 are broadly tuned to detect stimuli of different chemical classes, while others, such as TAS2R4, TAS2R5, $T A S 2 R 8$ and TAS2R43, appear to be more specific and activated by one or a few agonists [50-52]. It appears that different TAS2R alleles may have different profiles of ligand specificity [53-55]. The 
number of TAS2R genes may not, therefore, be a spectrum-limiting element for the receptors, which may include many variants each leading to a different ligand preference.

\section{The Role of Bitter Taste Receptors in Rhinosinusitis}

Recent data demonstrate that chronic rhinosinusitis (CRS) affects approximately $5-16 \%$ of the general population both in Europe [56] and the USA [57]. It is divided into two specific disease entities: chronic rhinosinusitis with (CRSwNP) and without nasal polyps (CRSsNP), and it depends on the presence of polypous lesions in the nasal cavities and/or paranasal sinuses. There are many factors attributed with a role in the etiopathogenesis of CRS, including allergy, congenital immunodeficiencies, ciliary impairment as in patients with Kartagener's syndrome, primary ciliary dyskinesia and cystic fibrosis, bacteria forming biofilms, environmental factors and genetic factors [58]. One of the genetic factors is the type of bitter taste receptor in the upper airway. The ability to regulate congenital immunity, especially in the respiratory system, is increasingly attributed to bitter taste receptors (TAS2Rs), especially TAS2R38 [59,60].

When epithelial cells are stimulated with known agonists of TAS2R38 such as phenylthiocarbamide (PTC), they exhibit low-level calcium responses that activate nitric oxide (NO) synthase (NOS) and lead to robust intracellular NO production [61]. In 2017, Yan et al. confirmed the same signalling pattern for TAS2R4 and TAS2R16 receptors present in sinonasal tissue [62]. This signalling pathway included two of the important components of the well-established taste signal transduction cascade, namely phospholipase $C$ isoform $\beta 2$ (PLC $\beta 2$ ) and the transient receptor potential cation channel subfamily $\mathrm{M}$ member 5 (TRPM5) ion channel (Figure 2).

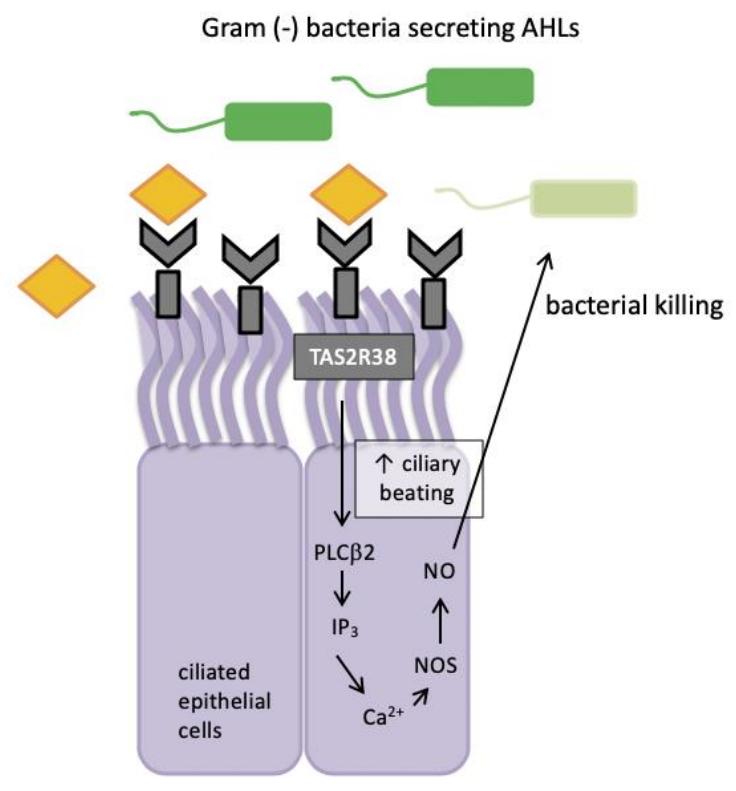

Figure 2. TAS2R38 bitter taste receptor regulation in human sinonasal epithelial innate immunity. AHLs = acyl-homoserine lactones; $\mathrm{Ca}^{2+}=$ calcium ion; $\mathrm{NO}=$ nitric oxide; $\mathrm{NOS}=$ nitric oxide synthase; PLC $\beta 2=$ phospholipase; $\mathrm{IP}_{3}=$ inositol trisphosphate.

Nitric oxide and its derivatives are damaging to bacterial membranes, enzymes and DNA. They also increase ciliary beat frequency through the activation of guanylyl cyclase and protein kinase G, which phosphorylate ciliary proteins that accelerate mucociliary clearance. The identification of physiologic ligands that activate TAS2R38 is further evidence in support of the role of TAS2R38 in airway immunity. Two major P. aeruginosa acyl-homoserine lactones (AHLs), N-butyryl-L-homoserine lactone (C4HSL) and N-3-oxo-dodecanoyl-L-homoserine lactone (C12HSL) [63,64], were identified as agonists of TAS2R38 [19]. Through studies with purified AHLs and conditioned medium from wild-type P. aeruginosa, it was demonstrated that TAS2R38 detects physiological concentrations of AHLs, 
which results in the activation of calcium-dependent NO production [65]. Many Gram negative species secrete AHLs and therefore, TAS2R38 is likely to function in airway ciliated cells as a sentinel receptor for detecting invading Gram negative bacteria, triggering a critical defensive bactericidal response.

Patients with the same risk factors of a similar age and of the same sex may have a completely different course of the disease. For years, clinicians have been looking for factors influencing the course of the disease and treatment in order to be able to propose treatment that is best suited to each patient. It was established that single nucleotide polymorphisms (SNPs) in the TAS2R38 gene may contribute to individual differences in susceptibility to respiratory infections, in particular, to chronic rhinosinusitis (CRS) $[55,66]$. The efficacy of this inborn immune defence within the nasal and sinus mucosa differs depending on the three most common polymorphisms in the TAS2R38 gene. The variants are associated with amino acid residues at positions 49 (rs713598 C/G p.Ala49Pro), 262 (rs1726866 G/. p.Ala262Val) and 296 (rs10246939 T/C p.Ile296Val). These three polymorphisms are connected and generate two common haplotypes. In the "protective" type, the TAS2R38 allele codes proline, alanine and valine (PAV), and in the "non-protective" type, the receptor allele codes alanine, valine and isoleucine (AVI), respectively. Patients who are homozygous PAV/PAV are considered "supertasters", AVI/AVI are "nontasters", and the heterozygous PAV/AVI show the widest range of bitter taste reception [1]. Other haplotypes, namely AVV, AAI, PAI and PVI, have been observed rarely $(1-5 \%)$ or in specific populations [67]. Many recently conducted studies show that people affected by chronic rhinosinusitis are much less likely to be PAV/PAV homozygotes $[68,69]$ (Table 2). Adappa et al. presented a pilot study in 2013 where they hypothesised that the PAV/PAV genotype would be less likely to occur in CRS patients who have failed medical therapy and require primary functional endoscopic sinus surgery (FESS) and that even after surgery these patients would have clinically improved outcomes in comparison with patients with PAV/AVI or AVI/AVI genotypes. Due to the small number of supertasters in this cohort, no conclusions could be reached but these initial suggestions led to further research [70]. This was followed by a subsequent prospective study in a bigger patient group $(\mathrm{N}=70)$ undergoing primary FESS. The distribution of diplotypes in the CRS patients was $37 \%$ AVI/AVI, 54\% AVI/PAV and 8.5\% PAV/PAV, which was significantly different from the distributions found in the general Philadelphia population. No significant differences were found in the allele distribution with respect to other risk factors, such as asthma, allergies, aspirin sensitivity, diabetes, smoking exposure or nasal polyposis, suggesting that TAS2R38 is an independent risk factor for CRS requiring FESS [71]. In 2016 the same authors defined the prognostic value of the PAV/PAV genotype as favourable in terms of outcome after surgery (QoL) in CRSsNS patients [72]. Dżaman et al. found TAS2R38 to be highly expressed in the sinonasal mucosa of CRS patients. The heterozygote frequency $(\mathrm{AVI} / \mathrm{PAV})$ was the highest and the protective genotype (PAV/PAV) was noticed in the lowest frequency and connected with a lower average value of CT score compared to AVI/AVI genotypes $(p=0.01)$ [73]. Cantone et al. confirmed that the nonfunctional genotype is more frequent among CRS patients than in the general population ( $25 \%$ vs. $18.4 \%$ ), that airway Gram negative infections are primarily associated with AVI and that biofilm formation is prevalent in CRS patients with the AVI nontaster phenotype, which confirmed an inverse correlation between TAS2R38 functionality and Gram negative infections in patients with CRSwNP [74,75]. Cohen et al. demonstrated that upper airway epithelial cells from individuals with one or two nonfunctional TAS2R38 alleles (AVI) have significantly blunted nitric oxide and ciliary responses following exposure to Gram negative quorum-sensing molecules and that these individuals are more likely to be infected with Gram negative bacteria such as Pseudomonas aeruginosa than those with two functional receptor alleles, and to develop CRS [76]. In contrary, an Italian research team published results questioning this theory. Gallo et al. reported no significant difference in the distribution of the three more common genotypes (PAV/PAV, PAV/AVI, AVI/AVI) by comparing CRS patients and healthy controls. They also found no significant differences in genotype distribution between CRSwNP and CRSsNP, nor any significant association between any CRS-related factors and a particular genotype in their study group [77]. 
Table 2. TAS2R38 polymorphisms in selected studies in patients with chronic rhinosinusitis (CRS) and cystic fibrosis (CF).

\begin{tabular}{ccccccc}
\hline Author & $\begin{array}{c}\text { Study } \\
\text { Group }\end{array}$ & $\begin{array}{c}\text { Pathological } \\
\text { Condition }\end{array}$ & Tissue & PAV/PAV & PAV/AVI & AVI/AVI \\
\hline Adappa 2013 [70] & 28 & CRS & $\begin{array}{c}\text { sinonasal tissue } \\
\text { samples }\end{array}$ & 1 & 14 & 13 \\
\hline Adappa 2014 [71] & 70 & CRS & $\begin{array}{c}\text { sinonasal tissue } \\
\text { samples }\end{array}$ & 6 & 38 & 26 \\
\hline Adappa 2016 [72] & 123 & CRS & $\begin{array}{c}\text { sinonasal tissue } \\
\text { samples }\end{array}$ & 27 & 96 & 6 \\
\hline Dżaman 2016 [73] & 20 & CRS & blood & 4 & 10 & 13 \\
\hline Gallo 2016 [77] & 53 & CRS & blood & 8 & 32 & 24 \\
\hline Adappa 2016 [78] & 49 & CF & $\begin{array}{c}\text { sinonasal tissue } \\
\text { samples }\end{array}$ & 7 & 14 & 13 \\
\hline Cohen 2017 [76] & 28 & CRS & $\begin{array}{c}\text { sinonasal tissue } \\
\text { samples }\end{array}$ & 1 & 31 \\
\hline Cantone 2018 [74] & 124 & CRS & saliva blood & 2 & 32 & 31 \\
\hline
\end{tabular}

Some new facts have been presented recently by Freund et al. and Hariri et al. on the role of TAS2Rs other than TAS2R38 in rhinosinusitis [33,34]. The presence of TAS2R4, TAS2R14 and TAS2R16 receptors was confirmed in the sinonasal cilia, and they were found to be activated by the Pseudomonas quinolone signal (2-heptyl-3-hydroxy-4-quinolone) and 4-hydroxy-2-heptyl quinolone.

The incipient role of TAS2R38 and its polymorphisms in chronic rhinosinusitis inspired a study involving patients with cystic fibrosis (CF) homozygous for the pathogenic $\triangle F 508$ mutation. Adappa et al. examined a group of 69 patients with a TAS2R38 genotype of PAV/PAV, PAV/AVI, or AVI/AVI and homozygous for the $\triangle F 508$ CF mutation [78]. Out of this group, they selected 49 patients aged 18-32 years. Subsequently, it was found that CF patients with TAS2R38 functional alleles (PAV/PAV) had better rhinologic quality of life scores (SNOT-22) compared to CF patients with non-functional PAV/AVI and AVI/AVI genotypes. They also found rhinologic symptoms to be significantly lower in $\mathrm{PAV} / \mathrm{PAV}$ patients than non-PAV/PAV patients. It can be speculated that the use of TAS2R38 as a genetic marker in CF patients offers a novel approach to evaluating sinonasal disease in this population and may ultimately help in future treatment modalities.

\section{TAS2R Receptors in Lower Airways}

Studies on the primary cilia of the lower respiratory tract and their numerous functions have also led to the discovery of taste receptors in their structure [79]. In 2009, Shah et al. hypothesised that motile cilia might sense noxious stimuli [15]. They examined airway epithelial samples isolated from eight human donors and proved that only ciliated epithelial cells expressed TAS2R receptors (TAS2R4, TAS2R38, TAS2R43 and TAS2R46). They were localised specifically in the cilia, which was done by acetylated $\alpha$-tubulin immunostaining. To determine whether the TAS2R signalling pathway was functional, Shah et al. applied bitter compounds (denatonium, thujone, salicin, quinine and nicotine) to differentiated human airway epithelia and measured changes in intracellular $\mathrm{Ca}^{2+}\left[\mathrm{Ca}^{2+}\right]_{\mathrm{i}}$ concentrations. They all induced transient, dose-dependent increases in intracellular $\mathrm{Ca}^{2+}$. Researchers have also determined the correlation between $\left[\mathrm{Ca}^{2+}\right]_{\mathrm{i}}$ increase and increased ciliary beat frequency of $\sim 25 \%$, and that this information can rapidly spread through gap junctions to adjacent nonciliated cells.

Deshpande et al. studied the TAS2R receptors in cultured human airway smooth muscle (ASM) and determined their potential role. They performed quantitative RT-PCR studies with primers for 25 TAS2R genes and discovered that TAS2R10, TAS2R14 and TAS2R31 were the most highly expressed in human ASM [16]. This discovery was confirmed by Jaggupilli et al. By studying cystic fibrosis 
bronchial epithelial cells (CuFi-1), normal bronchial epithelial cells (NuLi-1) and ASM cells, they confirmed the expression of TAS2Rs $(14,20>3,4,5,50>10,13,19)$ in CuFi-1 and NuLi-1. They also demonstrated that ASM almost exclusively expressed TAS2R10, TAS2R14 and TAS2R31 receptors [30]. A study by Deshpande et al. also linked the expression of bitter receptors to bitter tastant-mediated $\left[\mathrm{Ca}^{2+}\right]_{\mathrm{i}}$ signalling. The response to the increase in $\left[\mathrm{Ca}^{2+}\right]_{i}$ was ablated by the $\mathrm{G} \beta \gamma$ inhibitor gallein and the PLC $\beta$ inhibitor U73122, and partially inhibited by the inositol-3-phosphate $\left(\mathrm{IP}_{3}\right)$ receptor antagonist 2APB. However, the exact bronchodilatation mechanism itself is still not entirely certain. Deshpande et al. suggested that bitter tastants activate the canonical bitter taste signalling pathway (i.e., TAS2R-gustducin-phospholipase (PLC $\beta 2$ )- inositol 1,4,5-triphosphate receptor $\left[\mathrm{IP}_{3} \mathrm{R}\right]$ ) to increase focal $\mathrm{Ca}^{2+}$ release from the endoplasmic reticulum, which then activate large-conductance $\mathrm{Ca}^{2+}$-activated $\mathrm{K}^{+}$channels, thereby hyperpolarising the membrane [16]. However, Zhang et al. subsequently demonstrated through patch-clamp recordings that bitter tastants do not activate large-conductance $\mathrm{Ca}^{2+-}$-activated $\mathrm{K}^{+}$channels, rather they inhibit them [80]. However, it should be taken into account that while both research teams used chloroquine as the main bitter tastant, they performed tests on different types of tissues. Deshpande used cultured human ASM, and Zhang used mouse ASM cells.

These differences in outcomes inspired Zhang's research team to seek the ultimate answer by studying this process in freshly isolated ASM tissues and cells [81]. They revealed that bitter tastants reverse the increase in $\left[\mathrm{Ca}^{2+}\right]_{i}$ evoked by bronchoconstrictors, leading to bronchodilation. This reversal is mediated by the suppression of $\mathrm{L}$ - type voltage-dependent calcium channels (VDCCs) in a gustducin $\beta$ and $\gamma$ subunit-dependent, yet PLC $\beta 2$ - and IP ${ }_{3} R$-independent manner. It seems that TAS $2 R$ activation in ASM stimulates two opposing $\mathrm{Ca}^{2+}$ signalling pathways, both mediated by the $\mathrm{G} \beta$ and $\gamma$ subunits, which increases $\left[\mathrm{Ca}^{2+}\right]_{i}$ at rest, but blocks activated $\mathrm{L}_{-}$type VDCCs, reversing the contraction they cause. However, Grassin-Delyle et al., by studying human lung tissue obtained from macroscopically healthy parts of the lungs from 77 patients, established that none of the signalling pathways targeted by current bronchodilators, nor the inhibition of BKCa or L-type voltage-gated calcium channels, could fully explain the TAS2R agonist-induced relaxation of human isolated bronchi [20]. Evidently, the exact mechanism has not yet been precisely defined and requires further study, but the bronchodilatation potential of TAS2Rs cannot be underestimated. What is certain is that bitter tastants may represent a new class of compounds with potential as potent bronchodilators, and that their potential should be further exanimated.

These discoveries led to the initiation of research into the role of TAS2Rs in inflammatory processes in the lower respiratory tract, such as asthma or chronic obstructive pulmonary disease (COPD). Asthma is a chronic inflammatory disorder of the airways associated with increased airway hyperresponsiveness leading to recurrent episodes of wheezing, breathlessness, chest tightness and coughing [82]. The chronic airway inflammation of asthma is characterised by airway wall infiltration by T-lymphocytes of the T-helper (Th) type 2 phenotype, eosinophils, macrophages/monocytes and mast cells. COPD is a chronic inflammatory disease of the lower airways characterised by the destruction of the lung parenchyma (pulmonary emphysema), the inflammation of the peripheral airways (respiratory bronchiolitis) and the inflammation of the central airways. Dysfunction of ASM cells, a major cell type in the respiratory tree, plays a pivotal role in promoting the progression of these diseases and in contributing to the symptoms of these diseases. With their ability to contract and relax, these cells regulate the diameter and length of conducting airways, controlling dead space and resistance to airflow to and from gas-exchanging areas [83,84].

In 2013, Orsmark-Pietras et al. established that TAS2R receptors can be found on isolated leucocytes in a group of asthmatic and healthy children. The expression of all TAS2Rs was significantly greater in the lymphocyte population compared to monocytes in both groups [21]. The expression of most TAS2Rs was higher in children with severe asthma compared to the healthy controls, especially TAS2R13, TAS2R14 and TAS2R19. In asthmatic children, TAS2R5 expression in mixed-blood leukocytes also showed a statistically significant correlation with bronchial hyperresponsiveness to methacholine. Moreover, two of the bitter tastants, chloroquine and denatonium, were found to significantly inhibit 
the release of TNF $\alpha$, IL-13 and MCP-1. Chloroquine also inhibited the release of IL-1 $\beta$, IL-2, IL-4, IL-5, IL-10, IL-17, G-CSF, GM-CSF, IFN $\gamma$ and PGE2 in a dose-dependent manner. The presence of TAS2R receptors on monocytes and their functionality was confirmed by Gopallawa et al. [85].

On the other hand, Robinett et al. investigated TAS2R-mediated bronchodilatory effects in human ASM cells derived from asthmatic patients and controls. TAS2R expression and TAS2R-mediated bronchodilatory effects were found to be independent of the disease state and IL-13-induced inflammatory environment [86]. Sharma et al. investigated yet another important aspect of chronic inflammatory pulmonary disease: airway remodelling, which is a hallmark feature of asthma and COPD [87]. The findings from this study demonstrated the antimitogenic effect of TAS2R agonists. Mast cell infiltration of ASM in asthma is also one of the very important contributions to airway hyperresponsiveness in this medical condition [88]. Ekoff et al. examined the expression of nine TAS2R genes in human cord blood-derived mast cells (CBMCs), the mast cell line HMC1.2 and the mast cell line LAD-2 [25]. The first two mast cell lines expressed several TAS2Rs. CBMCs expressed TAS2R4, $46,14,19,20,3,10,13$ and 5 in decreasing order and HMC1.2 expressed TAS2R4, 3, 46, 14, 10, 5, 19, 13 and 20, also in decreasing order. More importantly, TAS2Rs mediated significant inhibition of the release of histamine and PGD2 from IgE-receptor-activated primary human mast cells, which suggests that TAS2R receptors may mediate anti-inflammatory responses. TAS2R expression and the effects of TAS2R agonists on lipopolysaccharide (LPS)-induced cytokine release in human lung macrophages (LMs) were studied by Grassin-Delyle et al. [36]. They found that 16 TAS2Rs are expressed in human LMs with the most abundant transcripts being of TAS2R8, 14, 19, 39 and 46. They established that TAS2R agonists inhibit LPS-induced cytokine release by LMs-a process that is not mediated by the release of IL-10.

Deshpande et al. and Zhang et al. suggested that bitter tastants may cause greater ASM relaxation than $\beta 2$ adrenergic agonists, the most commonly used bronchodilators for treating asthma and COPD $[16,81]$. However, there are still some doubts concerning this matter $[89,90]$. What is certain is that bitter tastants represent a new class of compounds with potential as potent bronchodilators, and that their potential should be further exanimated. One of the many challenging aspects in the development of TAS2Rs as therapeutic targets is the dearth of receptor subtype-specific agonists with a refined pharmacological profile. Although there are well-characterised bitter compounds at our disposal, agonist-receptor subtype promiscuity has forestalled progression to clinical trials [91,92].

\section{Bitter Taste Receptors in Other Systems and Diseases}

$T A S 2 R$ receptors were also found in many other internal organs and the skin. A study by Clark et al. indicated that TAS2Rs couple the detection of bitter-tasting compounds to changes in thyrocyte function and T3/T4 production [26]. By studying the human thyrocyte line (Nthy Ori 3-1) and 15 TAS2R bitter taste receptors, they discovered that TAS2R agonists inhibit TSH-dependent $\mathrm{Ca}^{2+}$ increases in thyrocytes. They also demonstrated that nonsynonymous coding SNP (rs5020531), located within the TAS2R42 gene, showed a significant association with elevated fT3 or fT4 levels. This indicates that any difference in the primary structure of a thyroid-expressed TAS2R is associated with differences in the circulating levels of thyroid hormones. Interestingly, the human heart also seems to sense bitter compounds through the expression of TAS2Rs on myocytes and fibroblasts [22]. TAS2R14 was found to be highly expressed in those tissues, and the authors suggested that TAS2Rs might be involved in adapting the heart's function in response to the presence of toxic substances in the blood. In addition, coding SNP (rs1376251) in TAS2R50 is believed to be associated with higher myocardial infarction risk $[93,94]$.

Lund et al. studied the possibilities for human bone marrow stromal-derived cells (MSCs) and vascular smooth muscle cells (VSMCs) to interact with their environment through novel receptors [23]. They found that both MSC and VSMC cells express the bitter taste receptor TAS2R46 and are fully functional. Another study by Wölfle showed TAS2R1 and TAS2R38 expression throughout the epidermis and weak expression in the basal cells [28]. The keratinocyte cell line HaCaT and human 
primary keratinocytes (HPKs) both expressed TAS2Rs and showed $\mathrm{Ca}^{2+}$ responses and increases in the expression of differentiation marker genes in response to both diphenidol and amarogentin. In 2018, Shaw et al. also studied the expression of TAS2Rs in human skin [35]. They demonstrated differences in the expression of bitter taste receptors according to sex, age and sun exposure. There were significantly lower expression levels in sun-exposed skin for TAS2R14, TAS2R30 and TAS2R42, but they were higher for TAS2R60. In skin from the suprapubic area, females' expression was significantly higher for TAS2R3, TAS2R4 and TAS2R8. In skin from the lower leg, females' expression was significantly lower for TAS2R3, TAS2R9 and TAS2R14. Additionally, there was a positive correlation between increasing age and the expression of the TAS2R5 gene, but only in non-sun-exposed skin.

Zheng et al. studied the problem of preterm birth focusing their work on finding new molecular targets that might mediate myometrial relaxation and possibilities for developing new classes of effective and safe tocolytics [32]. Considering that TAS2R receptors are an attractive target for smooth muscle relaxants Zheng studied their expression in human myometrium cells obtained from peripartum hysterectomies performed on multiparous reproductive-age women at the time of indicated deliveries for medical reasons (i.e., placenta accreta, postpartum hemorrhage resulting from uterine atony) and cultured hTERT-HM cells. Transcripts for TAS2R4/5/10/13/14 were detected in 25 freshly collected human myometrial tissues and for TAS2R3/4/5/7/8/10/13/14/31/39/42/43/45 and 50 in cultured hTERT-HM cells. This study also proved that bitter tastants such as chloroquine and 1,10-phenanthroline almost fully reverse OT- and $\mathrm{KCl}$-induced contraction of the human myometrium. This effect was greater than that of clinically used tocolytics such as $\mathrm{MgSO} 4$, indomethacin, nifedipine and albuterol. TAS2R14 was indicated as the receptor that mediates the chloroquine-induced effect on $\left[\mathrm{Ca}^{2+}\right]_{i}$ in human myometrial cells. Most recently, a study on semen cells and testis tissue was conducted by Governini et al. [38]. Sperm was donated by 15 Caucasian males undergoing fertility examination. Samples of testicular tissue were obtained from six patients undergoing diagnostic testicular biopsy for obstructive azoospermia. Sperm cells were examined before and after in vitro selection and capacitation. The researchers demonstrated that both human testis tissue and semen cells express TAS2Rs. Some inter-individual variation for a single TAS2R was established. TAS2R3/4/19 and TAS2R 43 were detectable in about $73 \%$ of semen samples (11/15), whereas TAS2R14 was found in $80 \%$ of the probes (12/15). Interestingly, again TAS2R14 was the most expressed bitter receptor subtype in both testis tissue and sperm cells. The authors also observed that in vitro capacitation significantly affects both the expression and the subcellular localisation of these receptors in isolated spermatozoa.

TAS2R expression was reported to be dysregulated and to potentially play a role in side-effects induced by antipsychotic drugs in the cortex of Parkinson's disease and schizophrenia patients $[95,96]$. Deckmann et al. reported the presence of solitary chemosensory cells (SCCs) in the human urethra. Their observations suggest that those cells may play a sentinel function as upon the detection of possibly toxic substances, a protective reflex pathway is initiated, resulting in increased urine flow, which might serve to flush pathogens out of the body [97]. Furthermore, TAS2R38 polymorphism (AVI/AVI) has been associated with the risk of dental caries [98]. Another extraordinary discovery by Wölfle et al. showed strong expression of TAS2R38 in the amniotic epithelium, syncytiotrophoblast and decidua cells of the human placenta. Diphenidol stimulation of these cells (JEG-3) demonstrated the functionality of the TAS2Rs by inducing calcium influx [29]. TAS2Rs thus appear to be located in different parts of the human body, and determining their exact significance requires further research.

\section{The Role of TAS2R Receptors in Eating Behaviours, Obesity and Diabetes}

Eating habits and preferences are modified by taste perception. The growing interest in the causes of specific eating behaviours has encouraged research into genetic conditioning. Taste perception differences are formed by variations in receptor function for sweet, fat, and bitter tastes. The consumption of vegetables rich in antioxidants may be lower in individuals with higher sensitivity to bitter tastants [13,99-101]. During our lifetime, our food preferences can be modified by socialisation, the environment in which we live and even culture. However, it has been proven that we also inherit 
some of these preferences [102]. Cont et al. investigated the differences in food intake in infants [37]. They genotyped 131 infants, of whom 45 were bitter-insensitive (genotype AVI/AVI) (34.3\%), and 86 (65.6\%) were bitter-sensitive. They were divided as follows: $28.2 \%$ PAV/PAV (37/131) and 37.4\% PAV/AVI (49/131). Infants who were insensitive to bitter taste were more likely to consume the whole first complementary food meal at the first attempt, compared to sensitive ones (either the AVI/PAV or PAV/PAV genotypes). Moreover, bitter-insensitive infants consumed the whole volume of the first complementary food in fewer days than bitter-sensitive ones. It appears that supertasters may also have a corresponding lower intake of high fat and high sugar foods [103]. This may protect the supertasters against becoming overweight or obese [104].

The TAS2R38 receptor was also linked to the avoidance of alcohol consumption [105] and cigarette smoking [106], which might have an impact on cardiovascular disease [107]. A large observational study in Spain revealed a significant association between obesity and the TAS2R38 AVI/AVI haplotype in females $(\mathrm{N}=1319)$. These associations were not observed in male participants, and they were more robust in subjects aged $<40$ years [108]. Those findings were further supported by a study that established a significant association between three TAS2R38 variants and body fat percentage in females [109]. Super-tasting was also shown to have an impact on body mass index (BMI) by lowering it [110]. A study by Sharma et al. also confirmed that female PTC tasters aged 14-16 years have a higher mean average skinfold, percentage of body fat, fat mass index and fat-free mass index [111]. In the oral cavity, TAS2Rs are involved in the perception of bitter tastants, while in the lower gastrointestinal (GI) tract they have roles in chemoreception and the regulation of GI function.

Ghrelin is a hunger hormone that is mainly produced by the X/A-like cells in rats or in human P/D1-type cells of the gastric oxyntic mucosa, and to a lesser extent in the small intestine. Quinine decreased plasma ghrelin levels in the fasting state [112,113] while glucose inhibited ghrelin secretion [114]. In 2019, Wang et al. studied the impact of obesity on ghrelin secretion and the role of TAS2R receptors in this process [115]. The entire stomach and part of the small intestine (duodenum and jejunum) were collected from circulatory death or brain death organ donors (lean). Part of the stomach and a segment of the jejunum were obtained from obese nondiabetic patients who had undergone sleeve gastrectomy or Roux-en-Y gastric bypass surgery. They discovered that TAS2R4, TAS2R10 and TAS2R3 were expressed in both the stomach and the jejunum, whereas TAS2R38 was only expressed in the jejunum. Additionally, the mRNA expression of TAS2R4, TAS2R10 and TAS2R38 was significantly altered by obesity in a tissue-dependent manner. The differences in mRNA expression between patient groups were BMI-dependent and were not related to age or gender. Chloroquine (TAS2R3/7/10/14/39 agonist), emetine (TAS2R1 agonist) and 1,10- phenanthroline (TAS2R5 agonist) also increased ghrelin secretion in a concentration-dependent manner in fundic cultures from obese patients. The effect of denatonium benzoate (DB) on ghrelin secretion mainly involves TAS2R10.

Latorre et al. studied TAS2R38 expression in the colonic mucosa and its role in overweight/obese $(\mathrm{OW} / \mathrm{OB})$ versus lean $(\mathrm{NW})$ patients. It was shown that TAS2R38 is expressed by the human colonic mucosa, where it is localised to distinct types of enteroendocrine cells (EEC), including cholecystokinin (CCK), and glucagon-like peptide-1 (GLP-1) and peptide YY (PYY) cells [31]. It is upregulated in overweight and obese subjects, as indicated by the marked and significant increase in the number of TAS2R38-IR cells without changes in the overall density of EEC cells in the colonic mucosa of OW/OB vs. NW subjects. Agonists of the same TAS2R, such as phenylthiocarbamide, were found to increase ATP-binding cassette B1 (ABCB1) expression and increase the efflux activity of ABCB1. This suggests that TAS2R signalling limits the absorption of bitter-tasting/toxic substances through the modulation of gut efflux membrane transporters [18].

The expression of transcripts encoding TAS2R family members, hT1R3 and G $\alpha$-gustducin in the human colon and the human intestinal endocrine cell lines (HuTu-80 and NCI-H716 cells) was confirmed by Rozengurt et al. The stimulation of HuTu- 80 or NCI-H716 cells with PTC induced a rapid increase in the intracellular $\mathrm{Ca}^{2+}$ concentration in these cells [14]. The identification of $\mathrm{G} \alpha$-gustducin and chemosensory receptors that perceive chemical components of ingested substances, including 
drugs and toxins, in open enteroendocrine L cells has important implications for understanding molecular sensing in the human gastrointestinal tract and for developing novel therapeutic compounds that modify the function of these receptors in the gut. Other TAS2R receptor ligands were found to have a role in gastrointestinal regulation. An extract of the plant Hoodia gordonii induced the release of CCK from the human enteroendocrine cell line HuTu-80, probably via the activation of the TAS2R14 receptor [17], while berberine stimulates GLP-1 secretion through the activation of TAS2Rs and the taste signalling pathway [27]. The expression of TAS2Rs, including cognate TAS2Rs for caffeine, was shown in human gastric epithelial cells of the corpus/fundus and in HGT-1 cells. Caffeine, generally known as a stimulant of gastric acid secretion (GAS), was discovered to stimulate proton secretion depending on one of its cognate receptors, TAS2R43 [116]. All these data have led to further research, including on pathological conditions like diabetes [117].

Dotson et al. conducted the Amish Family Diabetes Study. They assessed the association of taste receptor variants with indicators of glucose dysregulation, including a diagnosis of type 2 diabetes mellitus and high levels of blood glucose and insulin during an oral glucose tolerance test [118]. They reported that a TAS2R haplotype is associated with altered glucose and insulin homeostasis and that one SNP within this haplotype disrupts the normal responses of a single receptor, TAS2R9, to its cognate ligands ofloxacin, procainamide and pirenzapine. This led to the conclusion that a functionally compromised TAS2R receptor negatively impacts glucose homeostasis, providing an important link between alimentary chemosensation and metabolic disease. TAS2R receptors may be a new target for the treatment of diabetes. It is speculated that the large number of TAS2Rs expressed in the intestines, each with different ligand specificities, offers diverse targets that may allow for selectivity and specificity. Thus, exploring whether any known bitter-tasting drugs have positive effects on glucose homeostasis would be of interest $[119,120]$. So far, however, no drug discovery activities involving TAS1Rs and/or TAS2Rs for the potential treatment of type 2 diabetes appear to be underway.

\section{TAS2Rs' Impact on Longevity}

$T A S 2 R$ genes have been widely associated with individual differences in taste perception, food preferences, diet, nutrition, immune responses and pathophysiological mechanisms. Could it be that by regulating food absorption processing and metabolism, they modulate the ageing process? In 2012, Campa et al. investigated the possible associations between longevity and the common genetic variation at the three TAS2R clusters on chromosomes 5, 7 and 12 in a population of 941 individuals ranging in age from 20 to 106 years from the south of Italy [121]. They found that five polymorphisms were associated with longevity: three in the TAS2R16 gene (rs6466849, rs860170 and rs978739), one in the TAS2R4 gene (rs2233998) and two in the TAS2R5 (rs2227264) gene, but only rs978739 reached statistical significance. Melis et al. studied the differences in genotype distribution and haplotype frequency of the TAS2R38 gene in a group of 94 centenarian and near-centenarian inhabitants of Sardinia, Italy, while comparing them to two control cohorts of 18-35 years of age and 36-85 years of age [122]. Interestingly, the results showed an increased frequency of subjects carrying the homozygous genotype for the functional variant of TAS2R38 (PAV/PAV) and a decreased frequency of those with the homozygous genotype for the non-functional form (AVI/AVI) in the centenarian cohort, compared to those determined in the two control groups. These data suggest that TAS2R variants are involved in the molecular physiological mechanisms involved in the biological process of ageing.

\section{TAS2Rs in Cancer}

The constant search for new therapies and new possibilities to monitor the course of disease in oncology has directed scientists towards the bitter taste receptors. In 2014, Singh et al. reported a study on three different mammary epithelial cells: the highly metastatic breast cancer cell line MDA-MB-231, the poorly metastatic cell line MCF-7 and the non-cancerous mammary epithelial cell line MCF-10A [24]. They characterised the expression of TAS2R1, TAS2R4, TAS2R10, TAS2R38 and TAS2R49 in those cells, finding that TAS2R4 is expressed at $40-70 \%$ in mammary epithelial cells in 
comparison to the commonly used breast cancer marker proteins, estrogen receptor and E-cadherin. What is more, these endogenous TAS2Rs may be functional because an increase in intracellular calcium mobilisation was observed after the application of the bitter agonists quinine, dextromethorphan, and phenylthiocarbamide. In 2017, Jaggupilli et al. showed a significant difference in expression between normal and cancerous mammary cell lines for TAS2R14 and TAS2R20(49) [30]. To determinate the ultimate difference in TAS2R4 and TAS2R14 expression in those cells, in 2019, Singh et al. [123] studied the same lines of mammary cells and established that TAS2R4 and TAS2R14 expression patterns were dissimilar, with decreased levels of TAS2R4 and increased levels of TAS2R14 in breast cancer clinical samples compared to non-cancerous controls. The activation of TAS2Rs with their respective agonist elicited physiological responses in metastatic breast cancer cells, and no responses were seen in non-tumourigenic breast epithelial cells. Agonist activation of TAS2Rs induced anti-proliferative, pro-apoptotic and anti-migratory responses in highly metastatic breast cancer cells. Taken together, these findings demonstrate that the chemosensory TAS2R signalling network is involved in evoking physiological responses in the metastatic breast cancer cell line.

Ovarian and prostate cancers are among the most lethal gynaecological and urological cancers in the world [124]. Martin et al. decided to determine whether bitter taste receptors are expressed in those two types of cancer [125]. They investigated epithelial ovarian cell lines (OVCAR8, IgROV1, SKOV3, OVCAR4) and prostate cell lines (PC3, LNCaP, DU145, BPH1), finding that several TAS2R receptors are expressed in ovarian cancer, and that the transcriptional regulation of these receptor genes is variable in high-grade serous and low-grade serous ovarian cancer cell lines. The expression of TAS2R14 and TAS2R38 was repressed in nearly all ovarian cell lines, but TAS2R4 and TAS2R10 were increased compared to the control tissue samples. In prostate cancer cells, the expression of TAS2Rs was found to be largely decreased, except for TAS2R38 in PC3 cells.

In 2015, Wölfle et al. showed that the human neuroblastoma cell line SH-SY5Y is responsive to salicin, inducing neurite outgrowth in a TAS2R16- and Erk-mediated fashion [126].

Furthermore, the role of the TAS2R38 receptor in pancreatic cancer was studied. It was reported that TAS2R38 was expressed and localised intracellularly in lipid droplets of tumour cells from pancreatic cancer patients and tumour-derived cell lines. Stimulation with N-acetyl-dodecanoyl homoserine (AHL-12) and phenylthiourea (PTU) leads to the TAS2R38-mediated activation of key transcription factors. These results indicate the potential involvement of TAS2R38 in pancreatic cancer progression [127].

Yamaki et al. genotyped two TAS2R genes, TAS2R38 and TAS2R46, in Japanese cancer patients diagnosed with biliary tract cancer, hepatocellular carcinoma, pancreatic cancer, colorectal cancer and gastric cancer. They found that cancer risk is not associated with any TAS2R46 genotypes, although they confirmed that phenylthiocarbamide (PTC) non-tasters homozygous (AVI/AVI) for TAS2R38 were more frequent among Japanese cancer patients. Therefore, it might be considered to increase cancer risk [128].

In a cohort study of colorectal adenoma cases, researchers explored the association between colorectal adenoma risk, dietary intake and genetic variation in three TAS2R genes: TAS2R38 (rs713598, rs1726866, rs10246939), TAS2R16 (rs846672) and TAS2R50 (rs1376251). No significant associations were observed between the TAS2R38 PAV/PAV diplotype or TAS2R16 (rs846672) polymorphism and the selected diet variables [129]. A meta-analysis performed by Choi et al. showed that the TAS2R38 diplotype minimally modified the GI neoplasm risk. Further studies should be performed to verify these hypotheses and the true role of TAS2R38 in gastrointestinal carcinogenesis [130].

A study by Tsutsumi et al. examined the effect of chemotherapy and radiotherapy on the expression of taste receptors in lingual mucosa scrapings from head and neck cancer patients [131]. The tumour types included laryngeal, hypopharyngeal, pharyngeal and maxillary cancer, among others. In 17 patients with mild/moderate stomatitis, the mRNA levels of TAS2R5 mRNA were significantly and transiently increased after chemotherapy. Although the perception threshold of bitter taste remained unchanged, lingual mRNA levels of TAS2R 5 were significantly increased in patients 
who complained of phantogeusia after chemotherapy. Additionally, a genomic study on oral cancer patient cohorts demonstrated an association between a coding SNP (rs1015443) in the TAS2R13 gene and increased susceptibility to alcohol consumption. Considering that strong alcohol consumption is a risk factor for head and neck cancer, this discovery may have an important role and should be further investigated [132]. There is no doubt that further studies are needed to investigate the chemosensory role of TAS2Rs in cancer.

\section{Conclusions}

Over the past decade, bitter taste receptors have not only been found outside the mouth and throat, but their functions have been proved to go beyond just gustatory purposes. Their protective properties have been proven in both the upper and lower respiratory tracts by functioning in airway ciliated cells as a sentinel receptor for detecting invading Gram negative bacteria and triggering a critical defensive bactericidal response or mediating bronchodilatation. The polymorphism of TAS2R genes might be an important factor in predicting the course of chronic rhinosinusitis, defining the manner and intensity of the treatment proposed to patients. TAS2Rs may also play an important role in pathological states such as asthma or diabetes, creating new areas for developing new medicines using signalling pathways different from those used so far. Their presence in cancer cells may be used for monitoring treatment and possible recurrence. Indisputably, TAS2R receptors have a lot of information and potential that still needs to be revealed.

Author Contributions: Conceptualisation, W.P. and J.J.-Ś.; methodology, J.J.-Ś.; investigation, J.J.-Ś.; writingoriginal draft preparation, J.J.-Ś.; writing—review and editing, W.P and W.F.; visualisation, J.J.S.S.; supervision, W.P.; project administration, W.F. All authors have read and agreed to the published version of the manuscript.

Funding: This research received no external funding.

Conflicts of Interest: The authors declare no conflict of interest.

\section{Abbreviations}

\begin{tabular}{|c|c|}
\hline GPCRs & G protein-coupled receptors \\
\hline PTC & Phenylthiocarbamide \\
\hline GI & Gastrointestinal \\
\hline PYY & Peptide YY \\
\hline GIP & Gastric inhibitory peptide \\
\hline GLP-1 & Glucagon-like peptide-1 \\
\hline $\mathrm{PGD}_{2}$ & Prostaglandin D2 \\
\hline EEC & Enteroendocrine cells \\
\hline CCK & Cholecystokinin \\
\hline ASM & Airway smooth muscle \\
\hline PASM & Pulmonary artery smooth muscle \\
\hline LMs & Lung macrophages \\
\hline CBMCs & Cord blood-derived mast cells \\
\hline MSC & Mesenchymal stromal cells \\
\hline VSMC & Vascular smooth muscle cell \\
\hline WBC & White blood cells \\
\hline PDE & Phosphodiesterase \\
\hline cNMP & Cyclic nucleotide-inhibited channels \\
\hline PLC $\beta 2$ & Phospholipase $C$ isoform $\beta 2$ \\
\hline $\mathrm{IP}_{3}$ & Inositol trisphosphate \\
\hline $\mathrm{IP}_{3} \mathrm{RIII}$ & $\mathrm{IP}_{3}$ receptor type III \\
\hline TRP & Transient receptor potential proteins \\
\hline TRPM5 & Transient receptor protein M5 \\
\hline CRS & Chronic rhinosinusitis \\
\hline
\end{tabular}




$\begin{array}{ll}\text { CRSwNP } & \text { Chronic rhinosinusitis with nasal polyps } \\ \text { CRSsNP } & \text { Chronic rhinosinusitis without nasal polyps } \\ \text { NO } & \text { Nitric oxide } \\ \text { NOS } & \text { Nitric oxide synthase } \\ \text { AHLs } & \text { Acyl-homoserine lactones } \\ \text { C4HSL } & \text { N-butyryl-L-homoserine lactone } \\ \text { C12HSL } & \text { N-3-oxo-dodecanoyl-L-homoserine lactone } \\ \text { Ca }^{2+} & \text { Calcium ion } \\ \text { K }^{+} & \text {Potassium ion } \\ \text { SNPs } & \text { Single nucleotide polymorphisms } \\ \text { FESS } & \text { Functional endoscopic sinus surgery } \\ \text { QoL } & \text { Quality of life } \\ \text { CT } & \text { Computer tomography } \\ \text { CF } & \text { Cystic fibrosis } \\ \text { VDCCs } & \text { Voltage-dependent calcium channels } \\ \text { COPD } & \text { Chronic obstructive pulmonary disease } \\ \text { HPKs } & \text { Human primary keratinocytes } \\ \text { SCCs } & \text { Solitary chemosensory cells } \\ \text { BMI } & \text { Body mass index } \\ \text { DB } & \text { Denatonium benzoate } \\ \text { ABCB1 } & \text { ATP-binding cassette B1 } \\ \text { GAS } & \text { Gastric acid secretion } \\ \text { AHL-12 } & \text { N-acetyl-dodecanoyl homoserine } \\ \text { PTU } & \text { Phenylthiourea } \\ & \end{array}$

\section{References}

1. Drayna, D. Human Taste Genetics. Annu. Rev. Genomics Hum. Genet. 2005, 6, 217-235. [CrossRef]

2. Bachmanov, A.; Bosak, N.; Lin, C.; Matsumoto, I.; Ohmoto, M.; Reed, D.R.; Nelson, T.M. Genetics of Taste Receptors. Curr. Pharm. Des. 2014, 20, 2669-2683. [CrossRef] [PubMed]

3. Kikut-Ligaj, D.; Trzcielinska-Lorych, J. How taste works: Cells, receptors and gustatory perception. Cell. Mol. Biol. Lett. 2015, 20, 699-716. [CrossRef] [PubMed]

4. Lee, H.; Macpherson, L.J.; Parada, C.A.; Zuker, C.S.; Ryba, N.J.P. Rewiring the taste system. Nature 2017, 548, 330-333. [CrossRef] [PubMed]

5. Challis, R.C.; Ma, M. Sour taste finds closure in a potassium channel. Proc. Natl. Acad. Sci. USA 2016, 113, 246-247. [CrossRef]

6. Bushman, J.D.; Ye, W.; Liman, E.R. A proton current associated with sour taste: Distribution and functional properties. FASEB J. 2015, 29, 3014-3026. [CrossRef]

7. Carey, R.M.; Adappa, N.D.; Palmer, J.N.; Lee, R.J.; Cohen, N.A. Taste Receptors: Regulators of Sinonasal Innate Immunity. Laryngoscope Investig. Otolaryngol. 2016, 1, 88-95. [CrossRef]

8. Fox, A.L. Taste blindness. Science 1931, 73, 14.

9. Adler, E.; Hoon, M.A.; Mueller, K.L.; Chandrashekar, J.; Ryba, N.J.; Zuker, C.S. A novel family of mammalian taste receptors. Cell 2000, 100, 693-702.Behrens, M.; Meyerhof, W. Oral and extraoral bitter taste receptors. Results Probl. Cell Differ. 2010, 52, 87-99.

10. Behrens, M.; Meyerhof, W. Oral and extraoral bitter taste receptors. Results Probl. Cell Differ. 2010, 52, 87-99.

11. Avau, B.; Depoortere, I. The bitter truth about bitter taste receptors: Beyond sensing bitter in the oral cavity. Acta Physiol. 2016, 216, 407-420. [CrossRef] [PubMed]

12. Shaik, F.A.; Singh, N.; Arakawa, M.; Duan, K.; Bhullar, R.P.; Chelikani, P. Bitter taste receptors: Extraoral roles in pathophysiology. Int. J. Biochem. Cell. Biol. 2016, 77, 197-204. [CrossRef] [PubMed]

13. Mennella, J.A.; Pepino, M.Y.; Reed, D.R. Genetic and environmental determinants of bitter perception and sweet preferences. Pediatrics 2005, 115, e216-e222. [CrossRef]

14. Rozengurt, N.; Wu, S.; Chen, M.C.; Huang, C.; Sternini, C.; Rozengurt, E. Co-localization of the \{alpha\} subunit of gustducin with PYY and GLP-1 in L cells of human colon. Am. J. Physiol. Gastrointest. Liver Physiol. 2006, 291, G792-G802. [CrossRef] 
15. Shah, A.S.; Ben-Shahar, Y.; Moninger, T.O.; Kline, J.N.; Welsh, M.J. Motile cilia of human airway epithelia are chemosensory. Science 2009, 325, 1131-1134. [CrossRef]

16. Deshpande, D.A.; Wang, W.C.; McIlmoyle, E.L.; Robinett, K.S.; Schillinger, R.M.; An, S.S.; Sham, J.S.K.; Liggett, S.B. Bitter taste receptors on airway smooth muscle bronchodilate by localized calcium signaling and reverse obstruction. Nat. Med. 2010, 16, 1299-1304. [CrossRef] [PubMed]

17. Le Neve, B.; Foltz, M.; Daniel, H.; Gouka, R. The steroid glycoside H.g.-12 from Hoodia gordonii activates the human bitter receptor TAS2R14 and induces CCK release from HuTu-80 cells. Am. J. Physiol. Gastrointest. Liver Physiol. 2010, 299, G1368-G1375. [CrossRef] [PubMed]

18. Jeon, T.I.; Seo, Y.K.; Osborne, T.F. Gut bitter taste receptor signalling induces ABCB1 through a mechanism involving CCK. Biochem, J. 2011, 438, 33-37. [CrossRef]

19. Lee, R.J.; Xiong, G.; Kofonow, J.M.; Chen, B.; Lysenko, A.; Jiang, P.; Abraham, V.; Doghramji, L.; Adappa, N.D.; Palmer, J.N.; et al. T2R38 taste receptor polymorphisms underlie susceptibility to upper respiratory infection. J. Clin. Invest. 2012, 122, 4145-4159. [CrossRef]

20. Grassin-Delyle, S.; Abrial, C.; Fayad-Kobeissi, S.; Brollo, M.; Faisy, C.; Alvarez, J.C.; Naline, E.; Devillier, P. The expression and relaxant effect of bitter taste receptors in human bronchi. Respir. Res. 2013, 14, 134. [CrossRef]

21. Orsmark-Pietras, C.; James, A.; Konradsen, J.R.; Nordlund, B.; Soderhall, C.; Pulkkinen, V.; Pedroletti, C.; Daham, K.; Kupczyk, M.; Dahlén, B.; et al. Transcriptome analysis reveals upregulation of bitter taste receptors in severe asthmatics. Eur. Respir. J. 2013, 42, 65-78. [CrossRef]

22. Foster, S.R.; Porrello, E.R.; Purdue, B.; Chan, H.W.; Voigt, A.; Frenzel, S.; Hannan, R.D.; Moritz, K.M.; Simmons, D.G.; Molenaar, P.; et al. Expression, Regulation and Putative Nutrient-Sensing Function of Taste GPCRs in the Heart. PLoS ONE 2013, 8, e64579. [CrossRef] [PubMed]

23. Lund, T.C.; Kobs, A.J.; Kramer, A.; Nyquist, M.; Kuroki, M.T.; Osborn, J.; Lidke, D.S.; Low-Nam, S.T.; Blazar, B.R.; Tolar, J. Bone Marrow Stromal and Vascular Smooth Muscle Cells Have Chemosensory Capacity via Bitter Taste Receptor Expression. PLoS ONE 2013, 8, e58945. [CrossRef]

24. Singh, N.; Chakraborty, R.; Bhullar, R.P.; Chelikani, P. Differential expression of bitter taste receptors in non-cancerous breast epithelial and breast cancer cells. Biochem. Biophys. Res. Commun. 2014, 446, 499-503. [CrossRef]

25. Ekoff, M.; Choi, J.H.; James, A.; Dahlen, B.; Nilsson, G.; Dahlen, S.E. Bitter taste receptor (TAS2R) agonists inhibit IgE-dependent mast cell activation. J. Allergy Clin. Immunol. 2014, 134, 475-478. [CrossRef]

26. Clark, A.A.; Dotson, C.D.; Elson, A.E.T.; Voigt, A.; Boehm, U.; Meyerhof, W.; Steinle, N.I.; Munger, S.D. TAS2R bitter taste receptors regulate thyroid function. FASEB J. 2015, 29, 164-172. [CrossRef]

27. Yu, Y.; Hao, G.; Zhang, Q.; Hua, W.; Wang, M.; Zhou, W.; Zong, S.; Huang, M.; Wen, X. Berberine induces GLP-1 secretion through activation of bitter taste receptor pathways. Biochem. Pharmacol. 2015, 97, 173-177. [CrossRef]

28. Wölfle, U.; Elsholz, F.A.; Kersten, A.; Haarhaus, B.; Müller, W.E.; Schempp, C.M. Expression and functional activity of the bitter taste receptors TAS2R1 and TAS2R38 in human keratinocytes. Skin Pharmacol. Physiol. 2015, 28, 137-146. [CrossRef] [PubMed]

29. Wölfle, U.; Elsholz, F.A.; Kersten, A.; Haarhaus, B.; Schumacher, U.; Schempp, C.M. Expression and functional activity of the human bitter taste receptor TAS2R38 in human placental tissues and JEG-3 cells. Molecules 2016, 21, 306. [CrossRef] [PubMed]

30. Jaggupilli, A.; Singh, N.; Upadhyaya, J.; Sikarwar, A.S.; Arakawa, M.; Dakshinamurti, S.; Bhullar, R.P.; Duan, K.; Chelikani, P. Analysis of the expression of human bitter taste receptors in extraoral tissues. Mol. Cell. Biochem. 2017, 426, 137-147. [CrossRef] [PubMed]

31. Latorre, R.; Huynh, J.; Mazzoni, M.; Gupta, A.; Bonora, E.; Clavenzani, P.; Chang, L.; Mayer, E.A.; De Giorgio, R.; Sternini, C. Expression of the Bitter Taste Receptor, T2R38, in Enteroendocrine Cells of the Colonic Mucosa of Overweight/Obese vs. Lean Subjects. PLoS ONE 2016, 11, e0147468. [CrossRef]

32. Zheng, K.; Lu, P.; Delpapa, E.; Bellve, K.; Deng, R.; Condon, J.C.; Fogarty, K.; Lifshitz, L.M.; Simas, T.M.; Shi, F.; et al. Bitter taste receptors as targets for tocolytics in preterm labor therapy. FASEB J. 2017, 31, 4037-4052. [CrossRef]

33. Hariri, B.M.; McMahon, D.B.; Chen, B.; Freund, J.R.; Mansfield, C.J.; Doghramji, L.J.; Adappa, N.D.; Palmer, J.N.; Kennedy, D.W.; Reed, D.R.; et al. Flavones modulate respiratory epithelial innate immunity: Anti-inflammatory effects and activation of the T2R14 receptor. J. Biol. Chem. 2017, 292, 8484-8497. [CrossRef] 
34. Freund, J.R.; Mansfield, C.J.; Doghramji, L.J.; Adappa, N.D.; Palmer, J.N.; Kennedy, D.W.; Reed, D.R.; Jiang, P.; Lee, R.J. Activation of airway epithelial bitter taste receptors by Pseudomonas aeruginosa quinolones modulates calcium, cyclic-AMP, and nitric oxide signaling. J. Biol. Chem. 2018, 293, 9824-9840. [CrossRef]

35. Shaw, L.; Mansfield, C.; Colquitt, L.; Lin, C.; Ferreira, J.; Emmetsberger, J.; Reed, D.R. Personalized expression of bitter 'taste' receptors in human skin. PLoS ONE 2018, 13, e0205322. [CrossRef] [PubMed]

36. Grassin-Delyle, S.; Salvator, H.; Mantov, N.; Abrial, C.; Brollo, M.; Faisy, C.; Naline, E.; Couderc, L.J.; Devillier, P. Bitter Taste Receptors (TAS2Rs) in Human Lung Macrophages: Receptor Expression and Inhibitory Effects of TAS2R Agonists. Front. Physiol. 2019, 10, 1-13. [CrossRef]

37. Cont, G.; Paviotti, G.; Montico, M.; Paganin, P.; Guerra, M.; Trappan, A.; Demarini, S.; Gasparini, P.; Robino, A. TAS2R38 bitter taste genotype is associated with complementary feeding behavior in infants. Genes Nutr. 2019, 14, 1-7. [CrossRef]

38. Governini, L.; Semplici, B.; Pavone, V.; Crifasi, L.; Marrocco, C.; De Leo, V.; Arlt, E.; Gudermann, T.; Boekhoff, I.; Luddiet, A.; et al. Expression of Taste Receptor 2 Subtypes in Human Testis and Sperm. J. Clin. Med. 2020, 9, 264. [CrossRef]

39. McLaughlin, S.; McKinnon, P.; Margolskee, R. Gustducin is a taste-cell-specific G protein closely related to the transducins. Nature 1992, 357, 563-569. [CrossRef]

40. Wong, G.; Gannon, K.; Margolskee, R. Transduction of bitter and sweet taste by gustducin. Nature 1996, 381, 796-800. [CrossRef]

41. Huang, L.; Shanker, Y.; Dbuauskaite, J.; Zheng, J.; Yan, W.; Rosenzweig, S.; Spielman, A.I.; Max, M.; Margolskee, R.F. Gg13 colocalizes with gustducin in taste receptor cells and mediates IP3 responses to bitter denatonium. Nat. Neurosci. 1999, 2, 1055-1062. [CrossRef]

42. Margolskee, R.F. Molecular mechanisms of bitter and sweet taste transduction. J. Biol. Chem. 2002, $277,1-4$. [CrossRef] [PubMed]

43. Romanov, R.A.; Rogachevskaja, O.A.; Bystrova, M.F.; Jiang, P.; Margolskee, R.F.; Kolesnikov, S.S. Afferent neurotransmission mediated by hemichannels in mammalian taste cells. EMBO J. 2007, 26, 657-667. [CrossRef] [PubMed]

44. Liu, D.; Liman, E.R. Intracellular $\mathrm{Ca}^{2+}$ and the phospholipid PIP2 regulate the taste transduction ion channel TRPM5. Proc. Natl. Acad. Sci. USA 2003, 100, 15160-15165. [CrossRef]

45. Prawitt, D.; Monteilh-Zoller, M.K.; Brixel, L.; Spangenberg, C.; Zabel, B.; Fleig, A.; Penner, R. TRPM5 is a transient $\mathrm{Ca}^{2+}$ activated cation channel responding to rapid changes in $\left[\mathrm{Ca}^{2+}\right]_{i}$. Proc. Natl. Acad. Sci. USA 2003, 100, 15166-15171. [CrossRef] [PubMed]

46. Ullrich, N.D.; Voetsa, T.; Prenena, J.; Vennekensa, R.; Talaveraa, K.; Droogmansa, G.; Nilius, B. Comparison of functional proper-ties of the $\mathrm{Ca}^{2+}$-activated cation channels TRPM4 and TRPM5 from mice. Cell Calcium 2005, 37, 267-278. [CrossRef]

47. Zhang, Y.; Hoon, M.A.; Chandrashekar, J.; Mueller, K.L.; Cook, B.; Wu, D.; Zuker, C.S.; Ryba, N.J. Coding of sweet, bitter, and umami tastes: Different receptor cells sharing similar signaling pathways. Cell 2003, 112, 293-301. [CrossRef]

48. Glendinning, J.I. Is the bitter rejection response always adaptive? Physiol. Behav. 1994, 56, 1217-1227. [CrossRef]

49. Meyerhof, W.; Batram, C.; Kuhn, C.; Brockhoff, A.; Chudoba, E.; Bufe, B.; Appendino, G.; Behrens, M. The molecular receptive ranges of human TAS2R bitter taste receptors. Chem. Senses 2010, 35, 157-170. [CrossRef]

50. Behrens, M.; Brockhoff, A.; Kuhn, C.; Bufe, B.; Winnig, M.; Meyerhof, W. The human taste receptor hTAS2R14 responds to a variety of different bitter compounds. Biochem. Biophys. Res. Commun. 2004, 319, 479-485. [CrossRef]

51. Brockhoff, A.; Behrens, M.; Massarotti, A.; Appendino, G.; Meyerhof, W. Broad tuning of the human bitter taste receptor hTAS2R46 to various sesquiterpene lactones, clerodane and labdane diterpenoids, strychnine, and denatonium. J. Agric. Food Chem. 2007, 55, 6236-6243. [CrossRef]

52. Sainz, E.; Cavenagh, M.M.; Gutierrez, J.; Battey, J.F.; Northup, J.K.; Sullivan, S.L. Functional characterization of human bitter taste receptors. Biochem. J. 2007, 403, 537-543. [CrossRef]

53. Kim, U.K.; Drayna, D. Genetics of individual differences in bitter taste perception: Lessons from the PTC gene. Clin. Genet. 2005, 67, 275-280. [CrossRef]

54. Meyerhof, W. Elucidation of mammalian bitter taste. Rev. Physiol. Biochem. Pharmacol. 2005, 154, 37-72. 
55. Kim, U.; Wooding, S.; Ricci, D.; Jorde, L.B.; Drayna, D. Worldwide haplotype diversity and coding sequence variation at human bitter taste receptor loci. Hum. Mutat. 2005, 26, 199-204. [CrossRef]

56. Hastan, D.; Fokkens, W.J.; Bachert, C.; Newson, R.B.; Bislimovska, J.; Bockelbrink, A.; Bousquet, P.J.; Brozek, G.; Bruno, A.; Dahlén, S.E.; et al. Chronic rhinosinusitis in Europe-An underestimated disease. A GA(2)LEN study. Allergy 2011, 66, 1216-1223. [CrossRef] [PubMed]

57. Pleis, J.R.; Lucas, J.W.; Ward, B.W. Summary Health Statistics for U.S. Adults: National Health Interview Survey. Vital Health Stat. 2009, 2008, 1-157.

58. Fokkens, W.J.; Lund, V.J.; Mullol, J.; Bachert, C.; Alobid, I.; Baroody, F.; Cohen, N.; Cervin, A.; Douglas, R.; Gevaert, P.; et al. European Position Paper on Rhinosinusitis and Nasal Polyps 2012. Rhinol. Suppl. 2012, 23, 1-298.

59. Carey, R.M.; Lee, R.J.; Cohen, N.A. Taste Receptors in Upper Airway Immunity. Adv. Otorhinolaryngol. 2016, 79, 91-102. [PubMed]

60. Rowan, N.R.; Soler, Z.M.; Othieno, F.; Storck, K.A.; Smith, T.L.; Schlosser, R.J. Impact of bitter taste receptor phenotype upon clinical presentation in chronic rhinosinusitis. Int. Forum Allergy Rhinol. 2018, 8, 1013-1020. [CrossRef] [PubMed]

61. Carey, R.M.; Workman, A.D.; Yan, C.H.; Chen, B.; Adappa, N.D.; Palmer, J.N.; Kennedy, D.W.; Lee, R.J.; Cohen, N.A. Sinonasal T2R-mediated nitric oxide production in response to Bacillus cereus. Am. J. Rhinol. Allergy 2017, 31, 211-215. [CrossRef]

62. Yan, C.H.; Hahn, S.; McMahon, D.; Bonislawski, D.; Kennedy, D.W.; Adappa, N.D.; Palmer, J.N.; Jiang, P.; Lee, R.J.; Cohen, N.A. Nitric oxide production is stimulated by bitter taste receptors ubiquitously expressed in the sinonasal cavity. Am. J. Rhinol. Allergy. 2017, 31, 85-92. [CrossRef] [PubMed]

63. Jimenez, P.N.; Koch, G.; Thompson, J.A.; Xavier, K.B.; Cool, R.H.; Quax, W.J. The multiple signaling systems regulating virulence in Pseudomonas aeruginosa. Microbiol. Mol. Biol. Rev. 2012, 76, 46-65. [CrossRef]

64. Maurer, S.; Wabnitz, G.H.; Kahle, N.A.; Stegmaier, S.; Prior, B.; Giese, T.; Gaida, M.M.; Samstag, Y.; Hansch, G.M. Tasting Pseudomonas aeruginosa biofilms: Human neutrophils express the bitter receptor T2R38 as sensor for the quorum sensing molecule N-(3-oxododecanoyl)-1-homoserine lactone. Front. Immunol. 2015, 6, 369. [CrossRef]

65. Lee, R.J.; Hariri, B.M.; McMahon, D.B.; Chen, B.; Doghramji, L.; Adappa, N.D.; Palmer, J.N.; Kennedy, D.W.; Jiang, P.; Margolskee, R.F.; et al. Bacterial d-amino acids suppress sinonasal innate immunity through sweet taste receptors in solitary chemosensory cells. Sci. Signal. 2017, 10. [CrossRef]

66. Mfuna Endam, L.; Filali-Mouhim, A.; Boisvert, P.; Boulet, L.P.; Bossé, Y.; Desrosiers, M. Genetic variations in taste receptors are associated with chronic rhinosinusitis: A replication study. Int. Forum Allergy Rhinol. 2014, 4, 200-206. [CrossRef]

67. Deshaware, S.; Singhal, R. Genetic variation in bitter taste receptor gene TAS2R38, PROP taster status and their association with body mass index and food preferences in Indian population. Gene 2017, 627, 363-368. [CrossRef]

68. Lee, R.J.; Cohen, N.A. The emerging role of the bitter taste receptor T2R38 in upper respiratory infection and chronic rhinosinusitis. Am. J. Rhinol. Allergy 2013, 27, 283-286. [CrossRef]

69. Lee, R.J.; Cohen, N.A. Role of the bitter taste receptor T2R38 in upper respiratory infection and chronic rhinosinusitis. Curr. Opin. Allergy Clin. Immunol. 2015, 15, 14-20. [CrossRef]

70. Adappa, N.D.; Howland, T.J.; Palmer, J.N.; Kennedy, D.W.; Doghramji, L.; Lysenko, A.; Reed, D.R.; Lee, R.J.; Cohen, N.A. Genetics of the taste receptor T2R38 correlates with chronic rhinosinusitis necessitating surgical intervention. Int. Forum Allergy Rhinol. 2013, 3, 184-187. [CrossRef]

71. Adappa, N.D.; Zhang, Z.; Palmer, J.N.; Kennedy, D.W.; Doghramji, L.; Lysenko, A.; Reed, D.R.; Scott, T.; Zhao, N.W.; Owens, D.; et al. The bitter taste receptor T2R38 is an independent risk factor for chronic rhinosinusitis requiring sinus surgery. Int. Forum Allergy Rhinol. 2014, 4, 3-7. [CrossRef] [PubMed]

72. Adappa, N.D.; Farquhar, D.; Palmer, J.N.; Kennedy, D.W.; Doghramji, L.; Morris, S.A.; Owens, D.; Mansfield, C.; Lysenko, A.; Lee, R.J.; et al. TAS2R38 genotype predicts surgical outcome in nonpolypoid chronic rhinosinusitis. Int. Forum Allergy Rhinol. 2016, 6, 25-33. [CrossRef] [PubMed]

73. Dżaman, K.; Zagor, M.; Sarnowska, E.; Krzeski, A.; Kantor, I. The correlation of TAS2R38 gene variants with higher risk for chronic rhinosinusitis in Polish patients. Otolaryngol. Pol. 2016, 70, 13-18. [CrossRef] 
74. Cantone, E.; Negri, R.; Roscetto, E.; Grassia, R.; Catania, M.R.; Capasso, P.; Maffei, M.; Soriano, A.A.; Leone, C.A.; Iengo, M.; et al. In vivo Biofilm Formation, Gram-Negative Infections and TAS2R38 Polymorphisms in CRSw NP Patients. Laryngoscope 2018, 128, E339-E345. [CrossRef]

75. Adappa, N.D.; Truesdale, C.M.; Workman, A.D.; Doghramji, L.; Mansfield, C.; Kennedy, D.W.; Palmer, J.N.; Cowart, B.J.; Cohen, N.A. Correlation of T2R38 taste phenotype and in vitro biofilm formation from nonpolypoid chronic rhinosinusitis patients. Int. Forum Allergy Rhinol. 2016, 6, 783-791. [CrossRef]

76. Cohen, N.A. The genetics of the bitter taste receptor T2R38 in upper airway innate immunity and implications for chronic rhinosinusitis. Laryngoscope 2017, 127, 44-51. [CrossRef]

77. Gallo, S.; Grossi, S.; Montrasio, G.; Binelli, G.; Cinquetti, R.; Simmen, D.; Castelnuovo, P.; Campomenosi, P. TAS2R38 taste receptor gene and chronic rhinosinusitis: New data from an Italian population. BMC Med. Genet. 2016, 17, 54. [CrossRef]

78. Adappa, N.D.; Workman, A.D.; Hadjiliadis, D.; Dorgan, D.J.; Frame, D.; Brooks, S.; Doghramji, L.; Palmer, J.N.; Mansfield, C.; Reed, D.R.; et al. T2R38 genotype is correlated with sinonasal quality of life in homozygous $\Delta$ F508 cystic fibrosis patients. Int. Forum Allergy Rhinol. 2016, 6, 356-361. [CrossRef] [PubMed]

79. Singla, V.; Reiter, J.F. The primary cilium as the cell's antenna: Signaling at a sensory organelle. Science 2006, 313, 629-633. [CrossRef]

80. Zhang, C.H.; Chen, C.; Lifshitz, L.M.; Fogarty, K.E.; Zhu, M.S.; ZhuGe, R. Activation of BK channels may not be required for bitter tastant-induced bronchodilation. Nat. Med. 2012, 18, 648-650. [CrossRef]

81. Zhang, C.H.; Lifshitz, L.M.; Uy, K.F.; Ikebe, M.; Fogarty, K.E.; ZhuGe, R. The cellular and molecular basis of bitter tastant-induced bronchodilation. PLoS Biol. 2013, 11, e1001501. [CrossRef]

82. Caramori, G.; Adcock, I. Pharmacology of airway inflammation in asthma and COPD. Pulm. Pharmacol. Ther. 2003, 16, 247-277. [CrossRef]

83. Hershenson, M.B.; Brown, M.; Camoretti-Mercado, B.; Solway, J. Airway smooth muscle in asthma. Annu. Rev. Pathol. 2008, 3, 523-555. [CrossRef]

84. Tliba, O.; Panettieri, R.A. Noncontractile functions of airway smooth muscle cells in asthma. Annu. Rev. Physiol. 2009, 71, 509-535. [CrossRef] [PubMed]

85. Gopallawa, I.; Freund, J.R.; Lee, R.J. Bitter taste receptors stimulate phagocytosis in human macrophages through calcium, nitric oxide, and cyclic-GMP signaling. Cell Mol. Life Sci. 2020, 10, 1-16. [CrossRef]

86. Robinett, K.S.; Koziol-White, C.J.; Akoluk, A.; An, S.S.; Panettieri, R.A., Jr.; Liggett, S.B. Bitter taste receptor function in asthmatic and nonasthmatic human airway smooth muscle cells. Am. J. Respir. Cell Mol. Biol. 2014, 50, 678-683. [CrossRef]

87. Sharma, P.; Panebra, A.; Pera, T.; Tiegs, B.C.; Hershfeld, A.; Kenyon, L.C.; Deshpande, D.A. Anti-mitogenic effect of bitter taste receptor agonists on airway smooth muscle cells. Am. J. Physiol. Lung Cell. Mol. Physiol. 2015, 310, L365-L376. [CrossRef]

88. Brightling, C.E.; Bradding, P.; Symon, F.A.; Holgate, S.T.; Wardlaw, A.J.; Pavord, I.D. Mast-cell infiltration of airway smooth muscle in asthma. N. Engl. J. Med. 2002, 346, 1699-1705. [CrossRef]

89. Belvisi, M.G.; Dale, N.; Birrell, M.A.; Canning, B.J. Bronchodilator activity of bitter tastants in human tissue. Nat. Med. 2011, 17, 776-778. [CrossRef]

90. Morice, A.H.; Bennett, R.T.; Chaudhry, M.A.; Cowen, M.E.; Griffin, S.C.; Loubani, M. Effect of bitter tastants on human bronchi. Nat. Med. 2011, 17, 775. [CrossRef]

91. Nayak, A.P.; Villalba, D.; Deshpande, D.A. Bitter Taste Receptors: An Answer to Comprehensive Asthma Control? Curr. Allergy Asthma Rep. 2019, 19, 48. [CrossRef] [PubMed]

92. Nayak, A.P.; Shah, S.D.; Michael, J.V.; Deshpande, D.A. Bitter taste receptors for asthma therapeutics. Front. Physiol. 2019, 10, 884. [CrossRef] [PubMed]

93. Shiffman, D.; Ellis, S.G.; Rowland, C.M.; Malloy, M.J.; Luke, M.M.; Iakoubova, O.A.; Pullinger, C.R.; Cassano, J.; Aouizerat, B.E.; Fenwick, R.G.; et al. Identification of four gene variants associated with myocardial infarction. Am. J. Hum. Genet. 2005, 77, 596-605. [CrossRef]

94. Shiffman, D.; O’Meara, E.S.; Bare, L.A.; Rowland, C.M.; Louie, J.Z.; Arellano, A.R.; Lumley, T.; Rice, K.; Iakoubova, O.; Luke, M.M.; et al. Association of gene variants with incident myocardial infarction in the cardiovascular health study. Arterioscler. Thromb. Vasc. Biol. 2008, 28, 173-179. [CrossRef] [PubMed] 
95. Garcia-Esparcia, P.; Schluter, A.; Carmona, M.; Moreno, J.; Ansoleaga, B.; Torrejon-Escribano, B.; Gustincich, S.; Pujol, A.; Ferrer, I. Functional genomics reveals dysregulation of cortical olfactory receptors in Parkinson disease: Novel putative chemoreceptors in the human brain. J. Neuropathol. Exp. Neurol. 2013, 72, 524-539. [CrossRef] [PubMed]

96. Ansoleaga, B.; Garcia-Esparcia, P.; Pinacho, R.; Haro, J.M.; Ramos, B.; Ferrer, I. Decrease in olfactory and taste receptor expression in the dorsolateral prefrontal cortex in chronic schizophrenia. J. Psychiatr. Res. 2014, 60, 109-116. [CrossRef]

97. Deckmann, K.; Filipski, K.; Krasteva-Christ, G.; Fronius, M.; Althaus, M.; Rafiq, A.; Papadakis, T.; Renno, L.; Jurastow, I.; Wessels, L.; et al. Bitter triggers acetylcholine release from polymodal urethral chemosensory cells and bladder reflexes. Proc. Natl. Acad. Sci. USA 2014, 111, 8287-8292. [CrossRef]

98. Wendell, S.; Wang, X.; Brown, M.; Cooper, M.E.; DeSensi, R.S.; Weyant, R.J.; Crout, R.; McNeil, D.W.; Marazita, M.L. Taste genes associated with dental caries. J. Dent. Res. 2010, 89, 1198-1202. [CrossRef] [PubMed]

99. Glanville, E.V.; Kaplan, A.R. Food preference and sensitivity of taste for bitter compounds. Nature 1965, 205, 851-853. [CrossRef]

100. Duffy, V.B.; Bartoshuk, L.M. Food acceptance and genetic variation in taste. J. Am. Diet. Assoc. 2000, 100, 647-655. [CrossRef]

101. Kim, U.K.; Breslin, P.A.; Reed, D.; Drayna, D. Genetics of human taste perception. J. Dent. Res. 2004, 83, 448-453. [CrossRef]

102. Chamoun, E.; Mutch, D.M.; Allen-Vercoe, E.; Buchholz, A.C.; Duncan, A.M.; Spriet, L.L.; Haines, J.; Ma, D.W.L. Guelph Family Health Study; A review of the associations between single nucleotide polymorphisms in taste receptors, eating behaviors, and health. Crit. Rev. Food Sci. Nutr. 2018, 58, 194-207. [CrossRef]

103. Dinehart, M.E.; Hayes, J.E.; Bartoshuk, L.M.; Lanier, S.L.; Duffy, V.B. Bitter taste markers explain variability in vegetable sweetness, bitterness, and intake. Physiol. Behav. 2006, 87, 304-313. [CrossRef] [PubMed]

104. Turner, A.; Veysey, M.; Keely, S.; Scarlett, C.; Lucock, M.; Beckett, E.L. Interactions between bitter taste, diet and dysbiosis: Consequences for appetite and obesity. Nutrients 2018, 10, 1336. [CrossRef] [PubMed]

105. Duffy, V.B.; Davidson, A.C.; Kidd, J.R.; Kidd, K.K.; Speed, W.C.; Pakstis, A.J.; Reed, D.R.; Snyder, D.J.; Bartoshuk, L.M. Bitter receptor gene (TAS2R38), 6-n-propylthiouracil (PROP) bitterness and alcohol intake. Alcohol Clin. Exp. Res. 2004, 28, 1629-1637. [CrossRef]

106. Cannon, D.S.; Baker, T.B.; Piper, M.E.; Scholand, M.B.; Lawrence, D.L.; Drayna, D.T.; McMahon, W.M.; Villegas, G.M.; Caton, T.C.; Coon, H.; et al. Associations between phenylthiocarbamide gene polymorphisms and cigarette smoking. Nicotine Tob. Res. 2005, 7, 853-858. [CrossRef]

107. Duffy, V.B. Associations between oral sensation, dietary behaviors and risk of cardiovascular disease (CVD). Appetite 2004, 43, 5-9. [CrossRef] [PubMed]

108. Ortega, F.J.; Agüera, Z.; Sabater, M.; Moreno-Navarrete, J.M.; Alonso-Ledesma, I.; Xifra, G.; Botas, P.; Delgado, E.; Jimenez-Murcia, S.; Fernández-Garcíaet, J.C.; et al. Genetic variations of the bitter taste receptor TAS2R38 are associated with obesity and impact on single immune traits. Mol. Nutr. Food Res. 2016, 60, 1673-1683. [CrossRef]

109. Keller, M.; Liu, X.; Wohland, T.; Rohde, K.; Gast, M.T.; Stumvoll, M.; Kovacs, P.; Tonjes, A.; Bottcher, Y. TAS2R38 and its influence on smoking behavior and glucose homeostasis in the German Sorbs. PLoS ONE 2013, 8, e80512. [CrossRef]

110. Tepper, B.J.; Koelliker, Y.; Zhao, L.; Ullrich, N.V.; Lanzara, C.; d'Adamo, P.; Ferrara, A.; Ulivi, S.; Esposito, L.; Gasparini, P. Variation in the bitter-taste receptor gene TAS2R38, and adiposity in a genetically isolated population in Southern Italy. Obesity 2008, 16, 2289-2295. [CrossRef]

111. Sharma, K.; Kaur, G.K. PTC bitter taste genetic polymorphism, food choices, physical growth in body height and body fat related traits among adolescent girls from Kangra Valley, Himachal Pradesh (India). Ann. Hum. Biol. 2014, 41, 29-39. [CrossRef] [PubMed]

112. Deloose, E.; Corsetti, M.; Van Oudenhove, L.; Depoortere, I.; Tack, J. Intragastric infusion of the bitter tastant quinine suppresses hormone release and antral motility during the fasting state in healthy female volunteers. Neurogastroenterol. Motil. 2018, 30. [CrossRef] [PubMed] 
113. Iven, J.; Biesiekierski, J.R.; Zhao, D.; Deloose, E.; O’Daly, O.G.; Depoortere, I.; Tack, J.; Van Oudenhove, L. Intragastric quinine administration decreases hedonic eating in healthy women through peptide-mediated gut-brain signaling mechanisms. Nutr. Neurosci. 2018, 22, 850-862. [CrossRef] [PubMed]

114. Foster-Schubert, K.E.; Overduin, J.; Prudom, C.E.; Liu, J.; Callahan, H.S.; Gaylinn, B.D.; Thorner, M.O.; Cummings, D.E. Acyl and total ghrelin are suppressed strongly by ingested proteins, weakly by lipids, and biphasically by carbohydrates. J. Clin. Endocrinol. Metab. 2008, 93, 1971-1979. [CrossRef] [PubMed]

115. Wang, Q.; Liszt, K.I.; Deloose, E.; Canovai, E.; Thijs, T.; Farré, R.; Ceulemans, L.J.; Lannoo, M.; Tack, J.; Depoortere, I. Obesity alters adrenergic and chemosensory signaling pathways that regulate ghrelin secretion in the human gut. FASEB J. 2019, 33, 4907-4920. [CrossRef]

116. Liszt, K.I.; Ley, J.P.; Lieder, B.; Behrens, M.; Stöger, V.; Reiner, A.; Hochkogler, C.M.; Köck, E.; Marchiori, A.; Hans, J.; et al. Caffeine induces gastric acid secretion via bitter taste signaling in gastric parietal cells. Proc. Natl. Acad. Sci. USA 2017, 114, 6260-6269. [CrossRef]

117. Xie, C.; Wang, X.; Young, R.L.; Horowitz, M.; Rayner, C.K.; Wu, T. Role of intestinal bitter sensing in enteroendocrine hormone secretion and metabolic control. Front. Endocrinol. 2018, 9, 1-10. [CrossRef]

118. Dotson, C.D.; Zhang, L.; Xu, H.; Shin, Y.K.; Vigues, S.; Ott, S.H.; Elson, A.E.T.; Choi, H.J.; Shaw, H.; Egan, J.M.; et al. Bitter taste receptors influence glucose homeostasis. PLOS ONE 2008, 3, e3974. [CrossRef]

119. Dotson, C.D.; Vigues, S.; Steinle, N.I.; Munger, S.D. T1R and T2R receptors: The modulation of incretin hormones and potential targets for the treatment of type 2 diabetes mellitus. Curr. Opin. Investig. Drugs 2010, 11, 447-454.

120. Pham, H.; Hui, H.; Morvaridi, S.; Cai, J.; Zhang, S.; Tan, J.; Wu, V.; Levin, N.; Knudsen, B.; Goddard, W.A., 3rd; et al. A bitter pill for type 2 diabetes? The activation of bitter taste receptor TAS2R38 can stimulate GLP-1 release from enteroendocrine L-cells. Biochem. Biophys. Res. Commun. 2016, 475, 295-300. [CrossRef]

121. Campa, D.; de Rango, F.; Carrai, M.; Crocco, P.; Montesanto, A.; Canzian, F.; Rose, G.; Rizzato, C.; Passarino, G.; Barale, R. Bitter Taste Receptor Polymorphisms and Human Aging. PLoS ONE 2012, 7, e45232. [CrossRef] [PubMed]

122. Melis, M.; Errigo, A.; Crnjar, R.; Pes, G.M.; Tomassini Barbarossa, I. TAS2R38 bitter taste receptor and attainment of exceptional longevity. Sci. Rep. 2019, 9, 1-9. [CrossRef] [PubMed]

123. Singh, N.; Shaik, F.A.; Myal, Y.; Chelikani, P. Chemosensory bitter taste receptors T2R4 and T2R14 activation attenuates proliferation and migration of breast cancer cells. Mol. Cell. Biochem. 2020, 465, 199-214. [CrossRef] [PubMed]

124. Bray, F.; Ferlay, J.; Soerjomataram, I.; Siegel, R.L.; Torre, L.A.; Jemal, A. Global cancer statistics 2018: GLOBOCAN estimates of incidence and mortality worldwide for 36 cancers in 185 countries. CA Cancer J. Clin. 2018, 68, 394-424. [CrossRef] [PubMed]

125. Martin, L.T.P.; Nachtigal, M.W.; Selman, T.; Nguyen, E.; Salsman, J.; Dellaire, G.; Dupré, D.J. Bitter taste receptors are expressed in human epithelial ovarian and prostate cancers cells and noscapine stimulation impacts cell survival. Mol. Cell. Biochem. 2019, 454, 203-214. [CrossRef] [PubMed]

126. Wölfle, U.; Haarhaus, B.; Kersten, A.; Fiebich, B.; Hug, M.J.; Schempp, C.M. Salicin from willow bark can modulate neurite outgrowth in human neuroblastoma SH- SY5Y cells. Phytother. Res. 2015, 29, 1494-1500. [CrossRef] [PubMed]

127. Gaida, M.M.; Mayer, C.; Dapunt, U.; Stegmaier, S.; Schirmacher, P.; Wabnitz, G.H.; Hänsch, G.M. Expression of the bitter receptor T2R38 in pancreatic cancer: Localization in lipid droplets and activation by a bacteria-derived quorum-sensing molecule. Oncotarget 2016, 7, 12623-12632. [CrossRef]

128. Yamaki, M.; Saito, H.; Isono, K.; Goto, T.; Shirakawa, H.; Shoji, N.; Satoh-Kuriwada, S.; Sasano, T.; Okada, R.; Kudohet, K.; et al. Genotyping analysis of bitter-taste receptor genes TAS2R38 and TAS2R46 in Japanese patients with gastrointestinal cancers. J. Nutr. Sci. Vitaminol. (Tokyo) 2017, 63, 148-154. [CrossRef]

129. Schembre, S.M.; Cheng, I.; Wilkens, L.R.; Albright, C.L.; Marchand le, L. Variations in bitter-taste receptor genes, dietary intake, and colorectal adenoma risk. Nutr. Cancer 2013, 65, 982-990. [CrossRef]

130. Choi, J.H.; Kim, J. TAS2R38 Bitterness Receptor Genetic Variation and Risk of Gastrointestinal Neoplasm: A Meta-Analysis. Nutr. Cancer 2019, 71, 585-593. [CrossRef] 
131. Tsutsumi, R.; Goda, M.; Fujimoto, C.; Kanno, K.; Nobe, M.; Kitamura, Y.; Abe, K.; Kawai, M.; Matsumoto, H.; Sakaiet, T.; et al. Effects of chemotherapy on gene expression of lingual taste receptors in patients with head and neck cancer. Laryngoscope 2016, 126, E103-E109. [CrossRef] [PubMed]

132. Dotson, C.D.; Wallace, M.R.; Bartoshuk, L.M.; Logan, H.L. Variation in the gene TAS2R13 is associated with differences in alcohol consumption in patients with head and neck cancer. Chem. Senses 2012, 37, 737-744. [CrossRef] [PubMed]

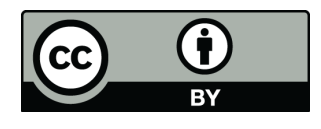

(C) 2020 by the authors. Licensee MDPI, Basel, Switzerland. This article is an open access article distributed under the terms and conditions of the Creative Commons Attribution (CC BY) license (http://creativecommons.org/licenses/by/4.0/). 